\title{
1 Dynamics of infection-elicited SARS-CoV-2 antibodies in children over time
}

2 Lauren E. Gentles ${ }^{\mathrm{a}, \mathrm{b}}$, Leanne Kehoe ${ }^{\mathrm{c}}$, Katharine H.D. Crawford ${ }^{\mathrm{a}, \mathrm{d}, \mathrm{e}}$, Kirsten Lacombe ${ }^{\mathrm{c}}$, Jane

3 Dickerson $^{\mathrm{c}, \mathrm{f}}$, Caitlin Wolf ${ }^{\mathrm{g}}$, Joanna Yuan ${ }^{\mathrm{c}}$, Susanna Schuler ${ }^{\mathrm{c}}$, John T. Watson ${ }^{\mathrm{h}}$, Sankan

4 Nyanseor $^{\mathrm{h}}$, Melissa Briggs-Hagen ${ }^{\mathrm{h}}$, Sharon Saydah $^{\mathrm{h}}$, Claire M. Midgley ${ }^{\mathrm{h}}$, Kimberly Pringle ${ }^{\mathrm{h}}$,

5 Helen $\mathrm{Chu}^{\mathrm{g}}$, Jesse D. Bloom ${ }^{\mathrm{a}, \mathrm{d}, \mathrm{i}} \#$, and Janet A. Englund ${ }^{\mathrm{c}, \mathrm{j}} \#$

$6 \quad{ }^{a}$ Division of Basic Sciences and Computational Biology Program, Fred Hutchinson Cancer

7 Research Center, Seattle, Washington, USA

$8{ }^{b}$ Department of Microbiology, University of Washington, Seattle, Washington, USA

9 'Division of Infectious Disease, Seattle Children's Hospital, Seattle, Washington, USA

$10{ }^{\mathrm{d}}$ Department of Genome Sciences, University of Washington, Seattle, Washington, USA

$11{ }^{\mathrm{e}}$ Medical Scientist Training Program, University of Washington, Seattle, Washington, USA

12 f Department of Laboratory Medicine and Pathology, University of Washington, Seattle,

13 Washington, USA

$14{ }^{\mathrm{g}}$ Division of Allergy and Infectious Diseases, University of Washington, Seattle, Washington, 15 USA

$16{ }^{\mathrm{h}}$ Division of Viral Diseases, Centers for Disease Control and Prevention, Atlanta, Georgia, USA

$17{ }^{\mathrm{i}}$ Howard Hughes Medical Institute, Seattle, Washington, USA

$18{ }^{\mathrm{j}}$ Department of Pediatrics, University of Washington, Seattle, Washington, USA

19 Running head: Longitudinal SAR-CoV-2 antibody dynamics in children 
medRxiv preprint doi: https://doi.org/10.1101/2022.01.14.22269235; this version posted January 25, 2022. The copyright holder for this preprint (which was not certified by peer review) is the author/funder, who has granted medRxiv a license to display the preprint in perpetuity. It is made available under a CC-BY 4.0 International license.

20 \# Address correspondence to Jesse D. Bloom, jbloom@ fredhutch.org, or Janet A. Englund,

21 janet.englund@seattlechildrens.org. 


\section{Abstract}

23 Severe acute respiratory syndrome coronavirus 2 (SARS-CoV-2) infection elicits an antibody

24 response that targets several viral proteins including spike $(\mathrm{S})$ and nucleocapsid $(\mathrm{N})$; $\mathrm{S}$ is the

25 major target of neutralizing antibodies. Here, we assess levels of anti-N binding antibodies and

26 anti-S neutralizing antibodies in unvaccinated children compared with unvaccinated older adults

27 following infection. Specifically, we examine neutralization and anti-N binding by sera collected

28 up to 52 weeks following SARS-CoV-2 infection in children and compare these to a cohort of

29 adults, including older adults, most of whom had mild infections that did not require

30 hospitalization. Neutralizing antibody titers were lower in children than adults early after

31 infection, but by 6 months titers were similar between age groups. The neutralizing activity of

32 the children's sera decreased modestly from one to six months; a pattern that was not

33 significantly different from that observed in adults. However, infection of children induced much

34 lower levels of anti-N antibodies than in adults, and levels of these anti-N antibodies decreased

35 more rapidly in children than in adults, including older adults. These results highlight age-related

36 differences in the antibody responses to SARS-CoV-2 proteins and, as vaccines for children are

37 introduced, may provide comparator data for the longevity of infection-elicited and vaccination-

38 induced neutralizing antibody responses.

\section{Keywords}

40 SARS-CoV-2, pediatric serology, neutralizing antibodies, anti-nucleocapsid antibodies,

41 longitudinal dynamics 


\section{Introduction}

44 SARS-CoV-2, the causative agent of coronavirus disease 2019 (COVID-19), elicits an antibody

45 response targeting multiple viral proteins following infection. Anti-spike (S) antibodies are of

46 particular importance because $\mathrm{S}$ is the major target of neutralizing antibodies and neutralizing

47 anti-S antibody titers correlate with protection (1-4). For this reason, currently authorized

48 vaccines only include the $S$ antigen and specifically induce anti-S responses. Additionally,

49 SARS-CoV-2 neutralization assays are designed to measure the potency of antibodies that block

50 viral binding and entry to cells, including via inhibiting $\mathrm{S}$ binding to host angiotensin converting

51 enzyme 2 (ACE2) receptor on host cells, and/or inhibiting $\mathrm{S}$ fusion. Nucleocapsid (N) protein is

52 also highly immunogenic during SARS-CoV-2 infection and is a predominant target of binding

53 antibodies making it a robust marker of infection. In adults, circulating antibodies rise to peak

54 titers within 3-5 weeks after infection and then gradually begin to wane (1, 3, 5-14). Studies

55 have shown a strong positive correlation between neutralizing antibody titers and protection from

56 subsequent infection $(4,15-19)$.

57 COVID-19 in children tends to be milder than in adults, resulting in lower risk of progression to

58 hospitalization and death $(20,21)$. However, clinical manifestations of COVID-19 vary widely in

59 children as in adults and can range from asymptomatic infections to illness lasting for several

60 months (22). Furthermore, infection by SARS-CoV-2 in children causes a greater burden of

61 hospitalization and death than the pre-vaccine burden of some common childhood illnesses,

62 including varicella (23). Previous work has documented the acute and convalescent dynamics of

63 the SARS-CoV-2 antibody response in adults across a wide range of ages and disease severities 
medRxiv preprint doi: https://doi.org/10.1101/2022.01.14.22269235; this version posted January 25, 2022. The copyright holder for this preprint (which was not certified by peer review) is the author/funder, who has granted medRxiv a license to display the preprint in perpetuity.

It is made available under a CC-BY 4.0 International license .

$64(1,3,8,10,11,14,23,24)$, but fewer data are available detailing the longevity of circulating antibodies in the pediatric population (24-27).

Here, we follow a cohort of 32 SARS-CoV-2-infected convalescent children <18 years old for up to 52 weeks post-symptom onset, measuring anti-S neutralizing antibody levels with a pseudoneutralization assay, and anti-N binding antibody levels. We compare the pediatric antibody response to those in a previously characterized cohort of adults (3).

Materials and Methods:

\section{Pediatric Participants}

72 Our IRB-approved study enabled us to enroll children, defined as $<18$ years old at enrollment,

73 including children with underlying medical conditions, and obtain sera for the assessment of

74 immune responses to SARS-CoV-2 infection at Seattle Children's Hospital, Seattle, WA,

75 beginning in April 2020. Informed consent was obtained from parents and assent from children over 7 years of age. The REDCap electronic data collection tool was used to acquire

77 demographics, hospitalization data; clinical information including respiratory support, ICU admission, length of stay; laboratory studies including viral testing results, and medical history

79 including chronic underlying medical conditions (28). This study was reviewed and approved by 80 the Seattle Children's Hospital IRB ${ }^{\S}$.

Children with confirmed or presumed SARS-CoV-2 infection were recruited to our study

82 during April 2020 through January 2021. Children were considered to have a confirmed SARS-

83 CoV-2 infection if they tested positive for SARS-CoV-2 by RT-PCR. Children were presumed to

84 have SARS-CoV-2 infection if they did not have documentation of a positive RT-PCR, but had

85 detectable SARS-CoV-2-specific antibodies and either: 1) presented with confirmed Multisystem 
medRxiv preprint doi: https://doi.org/10.1101/2022.01.14.22269235; this version posted January 25, 2022. The copyright holder for this preprint (which was not certified by peer review) is the author/funder, who has granted medRxiv a license to display the preprint in perpetuity.

It is made available under a CC-BY 4.0 International license .

Inflammatory Syndrome in Children (MIS-C), or 2) were symptomatic and had an RT-PCRpositive household contact. Reported symptoms included but were not limited to sore throat, cough, fever, loss of taste or smell, fatigue, runny nose, head ache, and diarrhea.

Enrollment included hospitalized children, children who were tested for SARS-CoV-2 using RTPCR as outpatients as determined by their provider, and children who did not receive medical care but were recruited from the community, including community-based surveillance platforms (29). Children were recruited during acute illness with sera drawn at approximately 4-8 weeks (1-2 months), 24 weeks (6 months), and 52 weeks (12 months) following symptom onset for confirmed or presumed infection. Only children who provided at least two specimens by May 2021 were included in this analysis. In addition, only presumed cases with at least one positive serological result were included (Supplemental Table 1). For asymptomatic cases, weeks postpositive RT-PCR test result was used as a substitute for weeks post-symptom onset. For children who developed MIS-C, "weeks post-symptom onset" refers to acute infection symptoms before MIS-C onset. No children in this study were vaccinated prior to specimen collection.

\section{Adult Participants}

Adult specimens were collected as a part of the Hospitalized or Ambulatory Adults with 
medRxiv preprint doi: https://doi.org/10.1101/2022.01.14.22269235; this version posted January 25, 2022. The copyright holder for this preprint (which was not certified by peer review) is the author/funder, who has granted medRxiv a license to display the preprint in perpetuity.

It is made available under a CC-BY 4.0 International license .

stay at Harborview Medical Hospital, University of Washington Medical Center, or Northwest Hospital in Seattle, Washington in 2020. Asymptomatic adults were identified as participants who responded "None" to a symptom questionnaire and tested positive for SARS-CoV-2 infection via outpatient or community testing. Informed consent was provided by all participants or their legally authorized representatives. No adults in this study were vaccinated prior to specimen collections since no vaccines were available during the collection period, and no adults in this study were enrolled in ongoing vaccine clinical trials. Weeks post-positive RT-PCR test result was used in lieu of weeks post-symptom onset for asymptomatic adults.

\section{Laboratory Methods}

\section{Pediatric specimen collection}

Whole blood collection was scheduled for 4 to 8-weeks, 24-weeks, and 52-weeks post-symptom onset for the pediatric cohort (Supplemental figure 1). Blood specimens were collected in serum separator tubes, stored at $5^{\circ} \mathrm{C}$, and spun within 24 hours before being aliquoted and stored at $-80 \square$. Heat inactivation of all specimens was performed at $56 \square$ for 30 minutes before performing serological assays.

\section{Adult specimen collection}

Whole blood collection was scheduled for 8- and 24-weeks post-symptom onset for the adult cohort. Blood specimens were immediately added to acid citrate dextrose tubes upon collection which were then spun down to separate out the red blood cell fraction. Within 6 hours following collection, aliquots of these specimens were frozen at $-20 \square$ for storage. Prior to use in serological assays, all specimens were heat inactivated at $56 \square$ for one hour. 
medRxiv preprint doi: https://doi.org/10.1101/2022.01.14.22269235; this version posted January 25, 2022. The copyright holder for this preprint (which was not certified by peer review) is the author/funder, who has granted medRxiv a license to display the preprint in perpetuity.

It is made available under a CC-BY 4.0 International license .

\section{Neutralization assays}

Neutralization assays were performed as previously reported using spike-pseudotyped lentiviral particles (3). The spike protein used is based on Wuhan-Hu-1 (GenBank: MN908947) with a 21 base pair deletion (delta21) at the terminus of the cytoplasmic tail that enhances viral titers (3237). The spike also contains the mutation $\mathrm{D} 614 \mathrm{G}$ that has become predominant in circulating strains (38). Plasmid HDM_Spikedelta21_D614G encoding this spike protein is available from AddGene (no. 155130) or BEI Resources (NR-53765) along with the full annotated sequence. To perform neutralization assays, $1.25 \times 10^{4}$ HEK-293T-ACE2 cells (39) (BEI resources NR-52511) are added in 50ul per well of a 96-well poly-L-lysine coated plate (Greiner; no. 655936). Our limit of detection for the neutralization assay is 1:20 since this is the starting serum dilution. All assays included pre-pandemic pooled serum collected between 2015 to 2018 as a negative control. No substantial neutralization was observed for a pool of pre-pandemic sera at a dilution of 1:20. SARS2 Spike-D614G-delta21 pseudotyped lentivirus particles encoding luciferase were added at a dilution of 200,000 RLU per well as determined by titering. The virus-antibody plate was then incubated for 1 hour at $37^{\circ} \mathrm{C}$ before being added to the plate with cells. Neutralization titers were determined using a plate reader to measure luciferase activity at 50 hours postinfection. Measurements were given as the reciprocal dilution of sera at which viral infection was inhibited by $50 \%\left(\mathrm{NT}_{50}\right)$. $\mathrm{NT}_{50}$ values were calculated using the neutcurve python package version 0.5.3 available here: https://github.com/jbloomlab/neutcurve which fit a Hill curve to our data to determine the $50 \%$ inhibitory concentration $\left(\mathrm{IC}_{50}\right)$. $\mathrm{NT}_{50}$ values reported here were the reciprocal of the $\mathrm{IC}_{50}$. 
medRxiv preprint doi: https://doi.org/10.1101/2022.01.14.22269235; this version posted January 25, 2022. The copyright holder for this preprint (which was not certified by peer review) is the author/funder, who has granted medRxiv a license to display the preprint in perpetuity.

It is made available under a CC-BY 4.0 International license.

151

152

153

154

155

156

157

158

159

160

161

162

163

164

165

166

167

168

169

170

171

\section{SARS-CoV-2 IgG assay}

The SARS-CoV-2 IgG assay, an FDA Emergency Use Authorized immunoassay, which utilizes a chemiluminescent test to assess immunoglobulin $\mathrm{G}(\mathrm{IgG})$ binding to nucleocapsid $(\mathrm{N})$ protein, was performed according to manufacturer specifications (Abbott). Anti-N IgG index values were assessed; higher index values reflected higher antibody levels. An index value of $>1.40$ is considered a positive result for this assay. Sensitivity and specificity of the SARS-CoV-2 IgG assay have been reported elsewhere $(23,40-44)$.

\section{Comparison of antibody levels in a subset of immunocompetent children and adults}

For comparison of antibody levels between pediatric participants and adults, we limited our analysis to only specimens that were collected within a similar range of weeks post-onset between 8-13 (first collection period) and 24-29 (second collection period) weeks for both cohorts. In this sub-analysis, we excluded participants with MIS-C development, complicating immunocompromising conditions, or receipt of multiple blood transfusions. We assessed changes in antibody titers over time among a limited number of children and adults with two specimens collected within these comparative time frames. Statistical significance was determined by Mann Whitney test.

\section{Results}

Study participants. From April 2020 through June 2021, we enrolled 97 pediatric participants of whom 42 had completed at least 6-months of follow-up with two blood draws obtained by May 2021 (Figure 1). Thirty-two of the 42 children had evidence of confirmed or presumed infection and were included in the pediatric analysis: 27 of 32 had a confirmed positive RT-PCR 
172 test, including one of two children who presented with MIS-C; one of 32 had a positive

173 serological test result and presented with MIS-C; and four of 32 had a positive serological test

174 result and a known RT-PCR-positive household member (Supplemental Table 1). Among the

17532 children included in this analysis, median age was 12 years, $6(19 \%)$ were female, $5(16 \%)$

176 were symptomatic and hospitalized, $25(78 \%)$ were symptomatic but not hospitalized, and 2

$177(6 \%)$ were asymptomatic during acute infection (Table 1, Figure 2). Of the two children who

178 developed MIS-C: one (C27) had an asymptomatic acute infection (identified through RT-PCR)

179 and subsequently required ICU admission and supplemental oxygen in the form of bilevel

180 positive airway pressure upon the onset of MIS-C symptoms; the other (C15) had an initial

181

182

183

184

185

186

187

188

189

190

191

192

193

194

SARS-CoV-2 respiratory infection managed as an outpatient but was subsequently hospitalized with MIS-C, during which time C15 was SARS-CoV-2 RNA-negative and antibody-positive.

Five children had underlying immunocompromising conditions or received multiple blood

transfusions; four of whom were hospitalized. Among the 25 children who were not

immunocompromised, did not receive multiple blood transfusions, and did not present with MIS-

C (Figure 2A), one child was hospitalized, 22 children were symptomatic but not hospitalized, and two children were asymptomatic.

A second cohort of 14 SARS-CoV-2-infected unvaccinated immunocompetent adults between the ages of 47 and 79 years (median: 65) was included in this study as a comparator group. We previously profiled neutralizing antibody dynamics for all these adults out to 90 days postsymptom onset (3) (See Supplemental Table 2). Here we performed additional assays for the same adult participants to enable direct comparison with the pediatric cohort in a sub-analysis.

This convenience sample of 14 adults included two who were symptomatic and hospitalized, 8 who were symptomatic non-hospitalized, and 4 who were asymptomatic. Eight (57\%) adults 
were female. Two adult participants reported underlying conditions: one participant (A3) was recorded as having diabetes, chronic obstructive pulmonary disease, asthma, and obstructive sleep apnea; and another (A13) had hypertension.

Specimen collection. During the 4- and 24-week pediatric blood collections, specimens were median of 9.5 (range: 8-13weeks, IQR:1wk) and 25 weeks (range: 24-29weeks, IQR: 1wk), respectively. To compare pediatric and adult responses, we performed a sub-analysis which included specimens collected within two collection periods: the first at 8-13 weeks, and the second at 24-29 weeks. This sub-analysis included specimens from all 14 adults; for children, 7 children had blood drawn in the first collection period (median $=9.5$ weeks; IQR $=2.5$ ) and 24 children had blood drawn in the second collection period (median 26 weeks; IQR=1). Five children and 14 adults, with specimens collected at both timepoints, were included in foldchange analyses.

Neutralization dynamics over time in children. We measured neutralization titers for the

212 confirmed or presumed infections had measurable neutralizing antibody titers for at least one 213 specimen. For the 25 children without MIS-C or immunocompromising conditions or multiple 214 blood transfusions, overall neutralization titers changed very little over the course of 24 weeks

215 from a geometric mean $\mathrm{NT}_{50}$ of 214 and 244 for the first and second collection period, respectively. Interestingly, a greater than 4-fold increase in neutralization titer between the first 
medRxiv preprint doi: https://doi.org/10.1101/2022.01.14.22269235; this version posted January 25, 2022. The copyright holder for this preprint (which was not certified by peer review) is the author/funder, who has granted medRxiv a license to display the preprint in perpetuity.

It is made available under a CC-BY 4.0 International license.

217 and second collection period was seen for four children all of whom were symptomatic but not

218 hospitalized. If these four children are excluded, the geometric mean $\mathrm{NT}_{50}$ decreases by 1.86 -fold

219 from the first to the second collection period (from 245 to 132, respectively). For two of the 25

220 children without immunocompromising conditions, a decrease of greater than 4-fold between 4

221 and 24 weeks was observed. Both children were symptomatic of whom one was hospitalized. For

$22219(76 \%)$ of the 25 children, less than 4-fold (range 3.86- to 1.02-fold) changes in neutralization

223 titers were observed. One child with increasing titers, (C32), had no detectable neutralization

224 titer at 3 weeks post-symptom onset despite testing positive by RT-PCR, but subsequently

225 developed high neutralization titers by 26 weeks. Despite the variability among individual

226 immunocompetent children, some trends in the overall antibody dynamics were observed

227 (Figure 3A). Nearly all immunocompetent children had neutralizing activity at all timepoints,

228 and the majority of children (15 out of the 25 total) exhibited at least a $25 \%$ decrease in

229 neutralization titers over 24 weeks.

230 For further clinical and laboratory data on children with underlying immunocompromising

231 conditions, multiple blood transfusions, or MIS-C, please refer to Figures $2 \mathrm{~B} \& \mathrm{C}$. Three

232 children with specimens at 52 weeks had detectable neutralizing antibodies (Figure 2A, B, \&

233 C). Of note, one child (C26) with blood collected at 52 weeks reported a febrile illness, with

234 negative SARS-CoV-2 RT-PCR, between the 24- and 52- week specimen collection (Figure

235 2C).

236 Comparison of neutralization dynamics in immunocompetent children and older adults.

237 We next compared neutralization titers and their longitudinal dynamics in children and adults. To

238 accomplish this, we measured plasma neutralizing antibody levels from adults over a 24-week 
medRxiv preprint doi: https://doi.org/10.1101/2022.01.14.22269235; this version posted January 25, 2022. The copyright holder for this preprint (which was not certified by peer review) is the author/funder, who has granted medRxiv a license to display the preprint in perpetuity.

It is made available under a CC-BY 4.0 International license .

239

240

241

242

243

244

245

246

247

248

249

250

251

252

253

254

255

256

257

258

259

260

261 period. Neutralization titers for specimens collected at 8- to 13-weeks post-symptom onset (first collection period) were previously reported using the same spike pseudotyped lentivirus neutralization assay but without the D614G spike mutation (3). Here, we repeated the neutralization assays using spike pseudotyped lentivirus encoding D614G as well as performing neutralization assays for the first time on specimens collected between 24 and 29 weeks (second collection period). Neutralization titers had a geometric mean of 385 (range: 56 - 4,487) and 302 (range: 67 - 880) at the first and second collection period, respectively (Supplemental figure 2).

Of the 14 participants in our adult cohort, only one demonstrated a greater than 4 -fold decrease in neutralization titer over the observation period, and no adults showed an increase greater than 4-fold. There were no adults for whom neutralization titers fell below the limit of detection during the timeframe tested.

For comparison of neutralization titers between the children and adults including older adults, we restricted our analysis to only specimens collected in the same timeframe for both cohorts, as well as only including children without immunocompromising conditions, those who did not receive multiple blood transfusions, and those without MIS-C. In this sub-analysis, we found that children had significantly lower neutralization potency (geometric mean titer $[\mathrm{GMT}]=118$, range: $46-256, \mathrm{~N}=7, p<0.05)$ than adults $(\mathrm{GMT}=385$, range: $56-4,487, \mathrm{~N}=14)$ during the first collection period, but titers were not significantly different between age groups by the second collection period (children: GMT=244, range: $27-13,694, \mathrm{~N}=22$; adults: GMT $=302$, range: 67 880, $\mathrm{N}=14 ; p=0.23$ ) (Figure 3B). If the four children with neutralization titers that increased by greater than 4-fold are excluded, the children's GMT for the second collection period is 2.46-fold lower than the adults' (123 compared to 302 in children and adults, respectively). We calculated the fold change in titers for each individual measured at the first collection period relative to 
medRxiv preprint doi: https://doi.org/10.1101/2022.01.14.22269235; this version posted January 25, 2022. The copyright holder for this preprint (which was not certified by peer review) is the author/funder, who has granted medRxiv a license to display the preprint in perpetuity.

It is made available under a CC-BY 4.0 International license.

262

263

264

265

266

267

268

269

270

271

272

273

274

275

276

277

278

279

280

281

282

those measured for the same individual during the second time period. Fold change analysis was limited to 5 children with specimens collected at both first and second collection period; no difference in the fold change between children (geometric mean fold decrease $=1.12, \mathrm{~N}=6$,) and adults (geometric mean fold decrease $=1.28, \mathrm{~N}=14)$ was detectable $(p=0.893)$. (Figure 3C).

Anti-nucleocapsid antibody dynamics over time in children. Anti-N antibody levels were determined for all pediatric specimens (Figure 4A, B, \& C). Among the 25 children without immunocompromising conditions, multiple blood transfusions, or MIS-C, 23 and 14 had detectable anti-N antibodies at the first and second collection periods, respectively; 2 children with confirmed infection by RT-PCR (C1 and C32) did not have detected anti-N antibodies at either timepoint. Anti-N antibody levels dropped considerably from a geometric mean index of 3.7 to 1.3 over 24 weeks. Eighteen of the 23 children, who were positive for anti-N antibodies at the first collection period, exhibited a decrease in index values of greater than 2 -fold, and an additional five changed less than 2-fold. No children showed an increase in anti-N antibodies. In totality, the children without immunocompromising conditions showed very similar declining trends in anti-N antibody levels across time (Figure 5A). Of the children with a positive index at 4 weeks, values ranged from 1.9 to 8.0 and from undetectable to 7.3 by the first and second collection periods, respectively.

For anti-N antibody levels and clinical information for the children with underlying immunocompromising conditions, multiple blood transfusions, or MIS-C refer to Figure 4B \& C. The antibody dynamics out to 52-weeks post-symptom onset were measured for three children all of whom had levels below the limit of detection by this later time period (Figure $\mathbf{4 A}, \mathbf{B}, \boldsymbol{\& C}$ ). 
medRxiv preprint doi: https://doi.org/10.1101/2022.01.14.22269235; this version posted January 25, 2022. The copyright holder for this preprint (which was not certified by peer review) is the author/funder, who has granted medRxiv a license to display the preprint in perpetuity.

It is made available under a CC-BY 4.0 International license .

\section{Comparison of pediatric and adult anti-nucleocapsid antibody dynamics. Next, we}

284

285

286

287

288

289

290

291

292

293

294

295

296

297

298

299

300

301

302

303

compared anti-N antibody dynamics in children and adults. We first measured anti-N antibody

levels for all adult specimens in our cohort (Supplemental figure 3). Overall, geometric mean

values in adults fell from 6.0 to 3.3 between the first and second collection period, respectively.

One adult (A12) had values below the limit of detection at both 8- and 24-weeks post-symptom

onset. Of the adults with a positive index at 8 weeks, values ranged from 4.2 to 9.4 and from 1.9

to 7.7 by the first and second collection period, respectively. No adults with positive index values

at the first timepoint fell below the limit of detection by the later timepoint. This is in stark

contrast to the pediatric cohort where many fell below detectable levels over the course of the

study. Furthermore, only 3 adults showed a greater than 2 -fold decrease in index values.

Compared to the pediatric cohort, adults had higher anti-N antibody levels at both timepoints measured although not quite reaching statistical significance at 8-13 weeks (children: GMT =

4.7, range: 3.0-6.2; adults: GMT $=6.0$, range: 0.8-9.4; $\mathrm{p}=0.053$ ) (Figure 5B). The difference

between adult and child index values was greatest at the later 24- to 29-week timepoint (children:

GMT $=1.2$, range: $0.2-7.3$; adults: GMT $=3.3$, range: $0.2-7.7 ; \mathrm{p}<0.0005)$ suggesting that anti-N

antibodies may wane faster in children than adults. To test this, we compared the fold change

between the first and second collection periods in children and in adults. We found a greater

decrease for the pediatric cohort (geometric mean decrease of 4-fold) demonstrating that these

children lost $\mathrm{N}$ antibody binding at a faster rate than the adult cohort (geometric mean decrease

of 1.8-fold) (Figure 5C).

\section{Discussion}


medRxiv preprint doi: https://doi.org/10.1101/2022.01.14.22269235; this version posted January 25, 2022. The copyright holder for this preprint (which was not certified by peer review) is the author/funder, who has granted medRxiv a license to display the preprint in perpetuity.

It is made available under a CC-BY 4.0 International license .

In this study, we describe the kinetics of serum antibodies over time in children after infection with SARS-CoV-2. In our convenience samples of unvaccinated children and adults with confirmed or presumed SARS-CoV-2 infection, we found that pediatric serum neutralizing titers were maintained over 24 weeks while anti-N-binding antibodies waned quickly. Importantly, neutralizing antibody titers were highly variable among individual children as has been

previously observed in adults $(1,3,6,8,10,11,23,24,45)$. Other studies have demonstrated that greater disease severity and higher viral load are associated with higher antibody levels in adults $(3,10,46)$. The limited number of asymptomatic, hospitalized, and MIS-C cases in our cohort prevented analysis of the role that disease severity may play in this variability. While further investigation is needed, the wide range of neutralization titers and anti-N antibody levels observed in our group of 22 immunocompetent, non-MIS-C presenting children, who were symptomatic but not hospitalized, suggests that disease severity may not entirely explain the observed heterogeneity.

There are several reasons why antibody responses to SARS-CoV-2 infection could be different in children compared to adults, including disease typically being less severe in children (21, 4751) as well as immune senescence and greater burden of comorbidities in older adults (52-58). Further, primary infections with respiratory pathogens tend to occur early in life leaving uncertainty about how antibody responses to primary infection may differ with age. Additionally, children are susceptible to life threatening MIS-C following infection, and it remains unclear if and/or how the immune response following infection may impact development of such sequelae.

Interestingly, only a modest and non-significant decrease in neutralizing antibody level was detected for pediatric specimens collected out to six months. A similar persistence in 
medRxiv preprint doi: https://doi.org/10.1101/2022.01.14.22269235; this version posted January 25, 2022. The copyright holder for this preprint (which was not certified by peer review) is the author/funder, who has granted medRxiv a license to display the preprint in perpetuity.

It is made available under a CC-BY 4.0 International license .

neutralization potency was also observed in the adult cohort, suggesting that there might be long term maintenance of neutralizing antibodies regardless of age following SARS-CoV-2 infection.

$$
\text { This finding is in line with several other bodies of work demonstrating the persistence of }
$$

neutralizing antibodies over many months $(9,26,59-61)$. We did, however, detect lower levels of neutralization in children's serum compared to adults early after infection. This finding is perhaps surprising given recent work, in the context of vaccination, showing that older adults, similar to the age group of adults reported here, develop lower neutralizing titers than younger adults (62). Antibody dynamics across ages may be different between infection and vaccination, and other factors such as specimen collection time or disease severity could also contribute the difference between this study and ours. Interestingly, by 24 weeks, a difference in neutralization titers between children and adults was no longer detectable. This leveling of neutralization titers over time has also been observed for some (3) but not all (11) studies of adults who have disease of different severity: adults with severe disease have higher initial titers at early, but not later, timepoints (3). Overall, the neutralizing antibody kinetics that we observe for children are similar to adults with mild infections $(3,14)$. A previous study corroborates our findings of lower pediatric neutralization titers early after infection by measuring neutralization titers in children and adults out to 60 days (24), and another study looking at only hospitalized children and adults reported the same (63). However, one study (26) found that younger children had higher titers than older children and adults. Differences in study population and sampling timepoints could explain these differences.

The most striking difference in SARS-CoV-2 antibody levels between children and adults was seen for anti-N antibodies. Although not statistically significant, children tended to have lower levels than adults early after infection and a significantly lower level after six months. Lower 
medRxiv preprint doi: https://doi.org/10.1101/2022.01.14.22269235; this version posted January 25, 2022. The copyright holder for this preprint (which was not certified by peer review) is the author/funder, who has granted medRxiv a license to display the preprint in perpetuity.

It is made available under a CC-BY 4.0 International license .

anti-N antibody levels in children than adults have been reported in another study as well (24).

Those authors speculated that, since nucleocapsid protein is disseminated during infection

through the lysis of infected cells, children may experience lower levels of $\mathrm{N}$ antigen expression due to their reduced duration of illness and potentially lower levels of viral replication (24). Alternatively, the cumulative lifetime exposure to betacoronavirus infections in adults may repeatedly boost antibodies to the more conserved nucleocapsid proteins that are cross-reactive to SARS-CoV-2, as has been observed for conserved influenza proteins (64). It is important to note that several studies have found that the SARS-CoV-2 IgG assay used for this study decreases in sensitivity over time faster than in other assays (13, 23, 40-44). In addition, the SARS-CoV-2 IgG assay only has emergency use authorization for qualitative assessment of antibodies and not quantitative.

Limitations of our study include small sample size, a limited number of children with follow-up at 52-weeks, and differences in the sex distribution between the pediatric and adult cohorts. Follow-up is ongoing with children who had not yet reached 52-weeks post-symptom onset at the time of this analysis. Furthermore, blood volume obtained from younger children is limited and therefore the number of assays utilized was also limited. The adult comparative specimens were obtained from the same geographic location and analyzed in the same laboratory, although not necessarily collected from the same families or at the same time. The adult specimens were also plasma, whereas the pediatric specimens were serum, and the differences in collection and storage of these could possibly result in slight differences in antibody concentrations. Additionally, the adults in this study were a convenience sample of a broader study, and approximately half were older adults, over 65 years of age, meaning that the data presented here may not be representative of all adults across wider age ranges. Likewise, our pediatric cohort 
medRxiv preprint doi: https://doi.org/10.1101/2022.01.14.22269235; this version posted January 25, 2022. The copyright holder for this preprint (which was not certified by peer review) is the author/funder, who has granted medRxiv a license to display the preprint in perpetuity.

It is made available under a CC-BY 4.0 International license.

372 was also a convenience sample and may also not be representative of the broader population.

373 Furthermore, unlike the pediatric cohort, adults were only enrolled following RT-PCR confirmed

374 infection without enrollment based on household RT-PCR positive contacts. Of note, both

375 children and adult cohorts were enrolled prior to the widespread introduction of the SARS-CoV-

3762 Delta variant.

377 Overall, our results suggest that although neutralizing antibody responses to SARS-CoV-2 are

378 broadly similar between adults and children, anti-N antibodies are elicited at lower levels in

379 children than adults. These results contribute to our knowledge of pediatric immune responses to

380 SARS-CoV-2 over time, and the data on the longevity of neutralizing antibodies may prove

381 valuable for comparison investigations of immunity induced by vaccines in children.

\section{Acknowledgements:}

383 The authors would like to acknowledge Andrea Loes for her supportive role in this study. This

384 work was supported by CDC BAA75D301-20-R-67897 and also by the NIAID/NIH

385 R01AI141707 and R01AI127893 grant to J.D.B. The findings and conclusions in this report are

386 those of the author(s) and do not necessarily represent the official position of the Centers for

387 Disease Control and Prevention (CDC). In addition, J.D.B. is an Investigator of the Howard

388 Hughes Medical Institute. This material is based upon work supported by the National Science

389 Foundation Graduate Research Fellowship Program under Grant No. DGE-1762114 to L.E.G.

390 Any opinions, findings, and conclusions or recommendations expressed in this material are those

391 of the author(s) and do not necessarily reflect the views of the National Science Foundation. The

392 funders had no role in study design, data collection, or the decision to submit the work for

393 publication. 
medRxiv preprint doi: https://doi.org/10.1101/2022.01.14.22269235; this version posted January 25, 2022. The copyright holder for this preprint (which was not certified by peer review) is the author/funder, who has granted medRxiv a license to display the preprint in perpetuity.

It is made available under a CC-BY 4.0 International license .

J.D.B consults for Moderna, Oncorus, and Flagship Labs 77. J.D.B. is an inventor on Fred Hutch licensed patents related to deep mutational scanning of viral proteins. J.A.E. consults for AstraZeneca, Sanofi Pasteur, Meissa Vaccines, Teva Pharmaceuticals, and receives research support from AstraZeneca, Merck, Novavax, and Pfizer. H.Y.C. receives research support from Gates Ventures, NIH, CDC, DARPA, Sanofi-Pasteur, and Cepheid and serves on the advisory boards for Merck, Pfizer, Ellume, and the Gates Foundation. All other authors report no additional competing interests.

Pediatric study design, patient enrollment and data acquisition, and specimen collection were

402 completed by J.A.E., L.K., K.L., J.Y., and S.S. Adults study design, patient enrollment and data 403 acquisition, and specimen collection was completed by H.Y.C. and L.W. Neutralization assays, 404 data analysis, and manuscript writing were performed by L.E.G. All work was performed under 405 the direction of J.D.B. and J.A.E. SARS-CoV-2 IgG assay were performed by J.D. Manuscript 406 editing and review was completed by J.D.B, J.A.E., H.Y.C., L.K., K.L., S.N., S.S., K.P., M.B.H, 407 and C.M.M.

\section{References:}

409 1. Wu J, Liang B, Chen C, Wang H, Fang Y, Shen S, Yang X, Wang B, Chen L, Chen Q, 410 Wu Y, Liu J, Yang X, Li W, Zhu B, Zhou W, Wang H, Li S, Lu S, Liu D, Li H, Krawczyk A, Lu

411 M, Yang D, Deng F, Dittmer U, Trilling M, Zheng X. 2021. SARS-CoV-2 infection induces

412 sustained humoral immune responses in convalescent patients following symptomatic COVID-

413 19. 1. Nature Communications 12:1813.

414 2. Shrock E, Fujimura E, Kula T, Timms RT, Lee I-H, Leng Y, Robinson ML, Sie BM, Li

415 MZ, Chen Y, Logue J, Zuiani A, McCulloch D, Lelis FJN, Henson S, Monaco DR, Travers M, 
424 Coronavirus 2 Infection. The Journal of Infectious Diseases

425 https://doi.org/10.1093/infdis/jiaa618.

426 4. Gilbert PB, Montefiori DC, McDermott A, Fong Y, Benkeser D, Deng W, Zhou H,

427 Houchens CR, Martins K, Jayashankar L, Castellino F, Flach B, Lin BC, O'Connell S, McDanal

429 Miller J, Sahly HME, Baden LR, Baron M, Cruz LDL, Gay C, Kalams S, Kelley CF, Kutner M,

432 (CoVPN)/Coronavirus, Teams and USG(USG)/CoVPN B. 2021. Immune Correlates Analysis 
6. Iyer AS, Jones FK, Nodoushani A, Kelly M, Becker M, Slater D, Mills R, Teng E,

Kamruzzaman M, Garcia-Beltran WF, Astudillo M, Yang D, Miller TE, Oliver E, Fischinger S,

TM, Branda JA, Turbett SE, LaRocque RC, Mellon G, Barouch DH, Schmidt AG, Azman AS,

442 Alter G, Ryan ET, Harris JB, Charles RC. 2020. Persistence and decay of human antibody

443 responses to the receptor binding domain of SARS-CoV-2 spike protein in COVID-19 patients.

$444 \quad$ Sci Immunol 5:eabe0367.

$4457 . \quad$ Wang K, Long Q-X, Deng H-J, Hu J, Gao Q-Z, Zhang G-J, He C-L, Huang L-Y, Hu J-L, 446 Chen J, Tang N, Huang A-L. 2020. Longitudinal Dynamics of the Neutralizing Antibody

447 Response to Severe Acute Respiratory Syndrome Coronavirus 2 (SARS-CoV-2) Infection.

448 Clinical Infectious Diseases https://doi.org/10.1093/cid/ciaa1143.

449 8. Seow J, Graham C, Merrick B, Acors S, Pickering S, Steel KJA, Hemmings O, O’Byrne 450 A, Kouphou N, Galao RP, Betancor G, Wilson HD, Signell AW, Winstone H, Kerridge C, 451 Huettner I, Jimenez-Guardeño JM, Lista MJ, Temperton N, Snell LB, Bisnauthsing K, Moore A, 452 Green A, Martinez L, Stokes B, Honey J, Izquierdo-Barras A, Arbane G, Patel A, Tan MKI, 453 O’Connell L, O’Hara G, MacMahon E, Douthwaite S, Nebbia G, Batra R, Martinez-Nunez R, 454 Shankar-Hari M, Edgeworth JD, Neil SJD, Malim MH, Doores KJ. 2020. Longitudinal 455 observation and decline of neutralizing antibody responses in the three months following SARS456 CoV-2 infection in humans. 12. Nature Microbiology 5:1598-1607.

457 9. Wajnberg A, Amanat F, Firpo A, Altman DR, Bailey MJ, Mansour M, McMahon M, 458 Meade P, Mendu DR, Muellers K, Stadlbauer D, Stone K, Strohmeier S, Simon V, Aberg J, 
Reich DL, Krammer F, Cordon-Cardo C. 2020. Robust neutralizing antibodies to SARS-CoV-2 infection persist for months. Science 370:1227-1230.

10. Wang Y, Zhang L, Sang L, Ye F, Ruan S, Zhong B, Song T, Alshukairi AN, Chen R, severity. J Clin Invest 130:5235-5244. assessed for up to 8 months after infection. Science 371 .

471 12. Gaebler C, Wang Z, Lorenzi JCC, Muecksch F, Finkin S, Tokuyama M, Cho A, Jankovic

472 M, Schaefer-Babajew D, Oliveira TY, Cipolla M, Viant C, Barnes CO, Bram Y, Breton G,

473 Hägglöf T, Mendoza P, Hurley A, Turroja M, Gordon K, Millard KG, Ramos V, Schmidt F,

474 Weisblum Y, Jha D, Tankelevich M, Martinez-Delgado G, Yee J, Patel R, Dizon J, Unson-

475 O’Brien C, Shimeliovich I, Robbiani DF, Zhao Z, Gazumyan A, Schwartz RE, Hatziioannou T,

476 Bjorkman PJ, Mehandru S, Bieniasz PD, Caskey M, Nussenzweig MC. 2021. Evolution of antibody immunity to SARS-CoV-2. Nature 591:639-644.

478 13. Muecksch F, Wise H, Batchelor B, Squires M, Semple E, Richardson C, McGuire J, 479 Clearly S, Furrie E, Greig N, Hay G, Templeton K, Lorenzi JCC, Hatziioannou T, Jenks S, 480 Bieniasz PD. 2021. Longitudinal Serological Analysis and Neutralizing Antibody Levels in 
Coronavirus Disease 2019 Convalescent Patients. The Journal of Infectious Diseases 223:389_ 398.

14. Wheatley AK, Juno JA, Wang JJ, Selva KJ, Reynaldi A, Tan H-X, Lee WS, Wragg KM, Kelly HG, Esterbauer R, Davis SK, Kent HE, Mordant FL, Schlub TE, Gordon DL, Khoury DS, Subbarao K, Cromer D, Gordon TP, Chung AW, Davenport MP, Kent SJ. 2021. Evolution of immune responses to SARS-CoV-2 in mild-moderate COVID-19. Nat Commun 12:1162.

15. Khoury DS, Cromer D, Reynaldi A, Schlub TE, Wheatley AK, Juno JA, Subbarao K, Kent SJ, Triccas JA, Davenport MP. 2021. Neutralizing antibody levels are highly predictive of immune protection from symptomatic SARS-CoV-2 infection. Nat Med https://doi.org/10.1038/s41591-021-01377-8.

498 infection protects against rechallenge in rhesus macaques. Science 369:812-817.

499 17. Deng W, Bao L, Liu J, Xiao C, Liu J, Xue J, Lv Q, Qi F, Gao H, Yu P, Xu Y, Qu Y, Li F, 500 Xiang Z, Yu H, Gong S, Liu M, Wang G, Wang S, Song Z, Liu Y, Zhao W, Han Y, Zhao L, Liu 501 X, Wei Q, Qin C. 2020. Primary exposure to SARS-CoV-2 protects against reinfection in rhesus 502 macaques. Science 369:818-823. 
503 18. Bergwerk M, Gonen T, Lustig Y, Amit S, Lipsitch M, Cohen C, Mandelboim M, Levin

504 EG, Rubin C, Indenbaum V, Tal I, Zavitan M, Zuckerman N, Bar-Chaim A, Kreiss Y, Regev-

505 Yochay G. 2021. Covid-19 Breakthrough Infections in Vaccinated Health Care Workers. New

506 England Journal of Medicine 385:1474-1484.

507 19. Addetia A, Crawford KHD, Dingens A, Zhu H, Roychoudhury P, Huang M-L, Jerome

508 KR, Bloom JD, Greninger AL. 2020. Neutralizing Antibodies Correlate with Protection from

509 SARS-CoV-2 in Humans during a Fishery Vessel Outbreak with a High Attack Rate. Journal of

$510 \quad$ Clinical Microbiology 58.

511 20. Chung E, Chow EJ, Wilcox NC, Burstein R, Brandstetter E, Han PD, Fay K, Pfau B,

512 Adler A, Lacombe K, Lockwood CM, Uyeki TM, Shendure J, Duchin JS, Rieder MJ, Nickerson

513 DA, Boeckh M, Famulare M, Hughes JP, Starita LM, Bedford T, Englund JA, Chu HY. 2021.

514 Comparison of Symptoms and RNA Levels in Children and Adults With SARS-CoV-2 Infection

515 in the Community Setting. JAMA Pediatr https://doi.org/10.1001/jamapediatrics.2021.2025.

516 21. Li B, Zhang S, Zhang R, Chen X, Wang Y, Zhu C. 2020. Epidemiological and Clinical

517 Characteristics of COVID-19 in Children: A Systematic Review and Meta-Analysis. Front

518 Pediatr 8:591132.

519 22. Molteni E, Sudre CH, Canas LS, Bhopal SS, Hughes RC, Antonelli M, Murray B, Kläser

520 K, Kerfoot E, Chen L, Deng J, Hu C, Selvachandran S, Read K, Capdevila Pujol J, Hammers A,

521 Spector TD, Ourselin S, Steves CJ, Modat M, Absoud M, Duncan EL. 2021. Illness duration and

522 symptom profile in symptomatic UK school-aged children tested for SARS-CoV-2. The Lancet

523 Child \& Adolescent Health S235246422100198X. 
524 23. Peluso MJ, Takahashi S, Hakim J, Kelly JD, Torres L, Iyer NS, Turcios K, Janson O,

525 Munter SE, Thanh C, Donatelli J, Nixon CC, Hoh R, Tai V, Fehrman EA, Hernandez Y, Spinelli

526 MA, Gandhi M, Palafox M-A, Vallari A, Rodgers MA, Prostko J, Hackett J, Trinh L, Wrin T,

527 Petropoulos CJ, Chiu CY, Norris PJ, DiGermanio C, Stone M, Busch MP, Elledge SK, Zhou

528 XX, Wells JA, Shu A, Kurtz TW, Pak JE, Wu W, Burbelo PD, Cohen JI, Rutishauser RL, Martin

529 JN, Deeks SG, Henrich TJ, Rodriguez-Barraquer I, Greenhouse B. 2021. SARS-CoV-2 antibody

530 magnitude and detectability are driven by disease severity, timing, and assay. Science Advances

$531 \quad 7: e a b h 3409$.

532 24. Weisberg SP, Connors TJ, Zhu Y, Baldwin MR, Lin W-H, Wontakal S, Szabo PA, Wells

533 SB, Dogra P, Gray J, Idzikowski E, Stelitano D, Bovier FT, Davis-Porada J, Matsumoto R, Poon

534 MML, Chait M, Mathieu C, Horvat B, Decimo D, Hudson KE, Zotti FD, Bitan ZC, La Carpia F,

535 Ferrara SA, Mace E, Milner J, Moscona A, Hod E, Porotto M, Farber DL. 2021. Distinct

536 antibody responses to SARS-CoV-2 in children and adults across the COVID-19 clinical

537 spectrum. 1. Nature Immunology 22:25-31.

538 25. Roarty C, Tonry C, McFetridge L, Mitchell H, Watson C, Waterfield T, Waxman E,

539 Fairley D, Roew-Setz G, McKenna J, Mallet P, Christy R, Christie K, McManus E, Bennison C,

540 Mullan K, Metryka A, Moore R, Ferris K, Watt A, McGinn C, Foster S, Evans J, Lyttle MD,

541 Ahmad S, Ladhani S, Corr M, Maney J-A, Christie S. 2020. Kinetics and seroprevalence of

542 SARS-CoV-2 antibodies in children. The Lancet Infectious Diseases

543 https://doi.org/10.1016/S1473-3099(20)30884-7.

544 26. Bonfante F, Costenaro P, Cantarutti A, Chiara CD, Bortolami A, Petrara MR, Carmona F,

545 Pagliari M, Cosma C, Cozzani S, Mazzetto E, Salvo GD, Dalt LD, Palma P, Barzon L, Corrao G, 

providing translational research informatics support. J Biomed Inform 42:377-381.

559 MJ, Adler A, Lacombe K, Kim AE, Graham C, Logue J, Wolf CR, Heimonen J, McCulloch DJ,

563 Platform. N Engl J Med 383:185-187.

564 30. Greaney AJ, Loes AN, Crawford KHD, Starr TN, Malone KD, Chu HY, Bloom JD.

565 2021. Comprehensive mapping of mutations in the SARS-CoV-2 receptor-binding domain that 566 affect recognition by polyclonal human plasma antibodies. Cell Host \& Microbe 29:463-476.e6. 
567 31. Garrett ME, Galloway J, Chu HY, Itell HL, Stoddard CI, Wolf CR, Logue JK, McDonald 568 D, Weight H, Matsen FA, Overbaugh J. 2021. High-resolution profiling of pathways of escape for SARS-CoV-2 spike-binding antibodies. Cell 184:2927-2938.e11.

571 S, Droit L, Ilagan MXG, Tartell MA, Amarasinghe G, Henderson JP, Miersch S, Ustav M, Sidhu

572 S, Virgin HW, Wang D, Ding S, Corti D, Theel ES, Fremont DH, Diamond MS, Whelan SPJ.

573 2020. Neutralizing Antibody and Soluble ACE2 Inhibition of a Replication-Competent VSV-

574 SARS-CoV-2 and a Clinical Isolate of SARS-CoV-2. Cell Host Microbe 28:475-485.e5.

575 33. Dieterle ME, Haslwanter D, Bortz RH, Wirchnianski AS, Lasso G, Vergnolle O, Abbasi

576 SA, Fels JM, Laudermilch E, Florez C, Mengotto A, Kimmel D, Malonis RJ, Georgiev G,

577 Quiroz J, Barnhill J, Pirofski L-A, Daily JP, Dye JM, Lai JR, Herbert AS, Chandran K, Jangra

578 RK. 2020. A Replication-Competent Vesicular Stomatitis Virus for Studies of SARS-CoV-2

579 Spike-Mediated Cell Entry and Its Inhibition. Cell Host Microbe 28:486-496.e6.

580 34. Johnson MC, Lyddon TD, Suarez R, Salcedo B, LePique M, Graham M, Ricana C, 581 Robinson C, Ritter DG. 2020. Optimized Pseudotyping Conditions for the SARS-COV-2 Spike 582 Glycoprotein. J Virol 94:e01062-20.

583 35. Ou X, Liu Y, Lei X, Li P, Mi D, Ren L, Guo L, Guo R, Chen T, Hu J, Xiang Z, Mu Z, 584 Chen X, Chen J, Hu K, Jin Q, Wang J, Qian Z. 2020. Characterization of spike glycoprotein of 585 SARS-CoV-2 on virus entry and its immune cross-reactivity with SARS-CoV. Nat Commun $586 \quad 11: 1620$.

587 36. Rogers TF, Zhao F, Huang D, Beutler N, Burns A, He W-T, Limbo O, Smith C, Song G, 588 Woehl J, Yang L, Abbott RK, Callaghan S, Garcia E, Hurtado J, Parren M, Peng L, Ramirez S, 
Ricketts J, Ricciardi MJ, Rawlings SA, Wu NC, Yuan M, Smith DM, Nemazee D, Teijaro JR, animal model. Science 369:956-963.

37. Schmidt F, Weisblum Y, Muecksch F, Hoffmann H-H, Michailidis E, Lorenzi JCC,

Mendoza P, Rutkowska M, Bednarski E, Gaebler C, Agudelo M, Cho A, Wang Z, Gazumyan A, viruses. J Exp Med 217:e20201181.

38. Korber B, Fischer WM, Gnanakaran S, Yoon H, Theiler J, Abfalterer W, Hengartner N, TM, de Silva TI, McDanal C, Perez LG, Tang H, Moon-Walker A, Whelan SP, LaBranche CC, 
40. Bryan A, Pepper G, Wener MH, Fink SL, Morishima C, Chaudhary A, Jerome KR, Mathias PC, Greninger AL. 2020. Performance Characteristics of the Abbott Architect SARSCoV-2 IgG Assay and Seroprevalence in Boise, Idaho. J Clin Microbiol 58:e00941-20.

614 for the detection of SARS-CoV-2 antibodies in comparison with neutralization activity.

615 EBioMedicine 62:103101. antibody detection. Pathology 53:773-779. Persistence of Anti-SARS-CoV-2 Antibodies Depends on the Analytical Kit: A Report for Up to 10 Months after Infection. 3. Microorganisms 9:556.

623 44. Theel ES, Johnson PW, Kunze KL, Wu L, Gorsh AP, Granger D, Roforth MM, Jerde 624 CR, Lasho M, Andersen KJ, Murphy BM, Harring J, Lake DF, Svarovsky SA, Senefeld JW, 625 Carter RE, Joyner MJ, Baumann NA, Mills JR. 2021. SARS-CoV-2 Serologic Assays Dependent 626 on Dual-Antigen Binding Demonstrate Diverging Kinetics Relative to Other Antibody Detection 627 Methods. J Clin Microbiol 59:e0123121. titres in SARS-CoV-2 infections. Nat Commun 12:63. 
631 46. Sun J, Tang X, Bai R, Liang C, Zeng L, Lin H, Yuan R, Zhou P, Huang X, Xiong Q,

632 Peng J, Cui F, Ke B, Su J, Liu Z, Lu J, Tian J, Sun R, Ke C. 2020. The kinetics of viral load and

633 antibodies to SARS-CoV-2. Clin Microbiol Infect 26:1690.e1-1690.e4.

634 47. Wu Z, McGoogan JM. 2020. Characteristics of and Important Lessons From the

635 Coronavirus Disease 2019 (COVID-19) Outbreak in China: Summary of a Report of $72 \square 314$

636 Cases From the Chinese Center for Disease Control and Prevention. JAMA 323:1239-1242.

637 48. Lu X, Zhang L, Du H, Zhang J, Li YY, Qu J, Zhang W, Wang Y, Bao S, Li Y, Wu C, Liu 638 H, Liu D, Shao J, Peng X, Yang Y, Liu Z, Xiang Y, Zhang F, Silva RM, Pinkerton KE, Shen K, 639 Xiao H, Xu S, Wong GWK. 2020. SARS-CoV-2 Infection in Children. New England Journal of 640 Medicine 382:1663-1665.

641 49. Bhopal SS, Bagaria J, Olabi B, Bhopal R. 2021. Children and young people remain at 642 low risk of COVID-19 mortality. The Lancet Child \& Adolescent Health 5:e12-e13.

643 50. Onder G, Rezza G, Brusaferro S. 2020. Case-Fatality Rate and Characteristics of Patients 644 Dying in Relation to COVID-19 in Italy. JAMA 323:1775-1776.

645 51. Dong Y, Mo X, Hu Y, Qi X, Jiang F, Jiang Z, Tong S. 2020. Epidemiology of COVID64619 Among Children in China. Pediatrics 145.

647 52. Kudesia P, Salimarouny B, Stanley M, Fortin M, Stewart M, Terry A, Ryan BL. 2021.

648 The incidence of multimorbidity and patterns in accumulation of chronic conditions: A

649 systematic review. J Comorb 11:26335565211032880. 
650 53. Franceschi C, Bonafè M, Valensin S, Olivieri F, De Luca M, Ottaviani E, De Benedictis

651

G. 2000. Inflamm-aging. An evolutionary perspective on immunosenescence. Ann N Y Acad Sci

652 908:244-254.

653 54. Palmer DB. 2013. The effect of age on thymic function. Front Immunol 4:316.

654 55. Salam N, Rane S, Das R, Faulkner M, Gund R, Kandpal U, Lewis V, Mattoo H, Prabhu 655 S, Ranganathan V, Durdik J, George A, Rath S, Bal V. 2013. T cell ageing: effects of age on 656 development, survival \& function. Indian J Med Res 138:595-608.

657 56. Dugan HL, Henry C, Wilson PC. 2020. Aging and influenza vaccine-induced immunity. 658 Cell Immunol 348:103998.

659 57. Wolff JL, Starfield B, Anderson G. 2002. Prevalence, Expenditures, and Complications 660 of Multiple Chronic Conditions in the Elderly. Archives of Internal Medicine 162:2269-2276.

661 58. Mueller AL, McNamara MS, Sinclair DA. 2020. Why does COVID-19

662 disproportionately affect older people? Aging (Albany NY) 12:9959-9981.

663 59. Isho B, Abe KT, Zuo M, Jamal AJ, Rathod B, Wang JH, Li Z, Chao G, Rojas OL, Bang

664 YM, Pu A, Christie-Holmes N, Gervais C, Ceccarelli D, Samavarchi-Tehrani P, Guvenc F,

665 Budylowski P, Li A, Paterson A, Yun YF, Marin LM, Caldwell L, Wrana JL, Colwill K, Sicheri 666 F, Mubareka S, Gray-Owen SD, Drews SJ, Siqueira WL, Barrios-Rodiles M, Ostrowski M, Rini

667 JM, Durocher Y, McGeer AJ, Gommerman JL, Gingras A-C. 2020. Persistence of serum and 668 saliva antibody responses to SARS-CoV-2 spike antigens in patients with COVID-19. Science 669 Immunology 5. 
670

671

672

673

674

675

676

677

678

679

680

681

682

683

684

685

686

687

688

689

690

60. Ripperger TJ, Uhrlaub JL, Watanabe M, Wong R, Castaneda Y, Pizzato HA, Thompson MR, Bradshaw C, Weinkauf CC, Bime C, Erickson HL, Knox K, Bixby B, Parthasarathy S, Chaudhary S, Natt B, Cristan E, El Aini T, Rischard F, Campion J, Chopra M, Insel M, Sam A, Knepler JL, Capaldi AP, Spier CM, Dake MD, Edwards T, Kaplan ME, Scott SJ, Hypes C, Mosier J, Harris DT, LaFleur BJ, Sprissler R, Nikolich-Žugich J, Bhattacharya D. 2020. Orthogonal SARS-CoV-2 Serological Assays Enable Surveillance of Low-Prevalence Communities and Reveal Durable Humoral Immunity. Immunity 53:925-933.e4.

61. Chia WN, Zhu F, Ong SWX, Young BE, Fong S-W, Bert NL, Tan CW, Tiu C, Zhang J, Tan SY, Pada S, Chan Y-H, Tham CYL, Kunasegaran K, Chen MI-C, Low JGH, Leo Y-S, Renia L, Bertoletti A, Ng LFP, Lye DC, Wang L-F. 2021. Dynamics of SARS-CoV-2 neutralising antibody responses and duration of immunity: a longitudinal study. The Lancet Microbe 2:e240e249.

62. Brockman MA, Mwimanzi F, Lapointe HR, Sang Y, Agafitei O, Cheung P, Ennis S, Ng K, Basra S, Lim LY, Yaseen F, Young L, Umviligihozo G, Omondi FH, Kalikawe R, Burns L, Brumme CJ, Leung V, Montaner JSG, Holmes D, DeMarco M, Simons J, Pantophlet R, Niikura M, Romney MG, Brumme ZL. 2021. Reduced magnitude and durability of humoral immune responses by COVID-19 mRNA vaccines among older adults.

63. Pierce CA, Preston-Hurlburt P, Dai Y, Aschner CB, Cheshenko N, Galen B, Garforth SJ, Herrera NG, Jangra RK, Morano NC, Orner E, Sy S, Chandran K, Dziura J, Almo SC, Ring A, Keller MJ, Herold KC, Herold BC. 2020. Immune responses to SARS-CoV-2 infection in hospitalized pediatric and adult patients. Science Translational Medicine 12:eabd5487. 
691 64. Jung J, Mundle ST, Ustyugova IV, Horton AP, Boutz DR, Pougatcheva S, Prabakaran P,

692 McDaniel JR, King GR, Park D, Person MD, Ye C, Tan B, Tanno Y, Kim JE, Curtis NC,

693 DiNapoli J, Delagrave S, Ross TM, Ippolito GC, Kleanthous H, Lee J, Georgiou G. 2021.

694 Influenza vaccination in the elderly boosts antibodies against conserved viral proteins and egg-

695 produced glycans. J Clin Invest 131.

697 Main text tables and figure legends:

698 Table 1. Pediatric and adult cohort demographics by disease severity.

\begin{tabular}{|c|c|c|c|c|}
\hline Characteristic & $\begin{array}{l}\text { Asymptomatic } \\
\qquad \mathrm{n}=2\end{array}$ & $\begin{array}{c}\text { Symptomatic } \\
\text { non-hospitalized } \\
n=25\end{array}$ & $\begin{array}{c}\text { Symptomatic } \\
\text { hospitalized } \\
n=5\end{array}$ & $\begin{array}{c}\text { Overall } \\
\mathrm{n}=32\end{array}$ \\
\hline Age, median (range) & $10(9.3-10.7)$ & $11.8(0.2-17.8)$ & $16(3.6-17.7)$ & $\begin{array}{c}12(0.2 \\
17.8)\end{array}$ \\
\hline \multicolumn{5}{|l|}{ Sex, no. (\%) } \\
\hline Female & $0(0)$ & $4(16)$ & $2(40)$ & $6(19)$ \\
\hline Male & $2(100)$ & $21(84)$ & $3(60)$ & $26(81)$ \\
\hline $\begin{array}{l}\text { Immunocompromised or received } \\
\text { multiple blood transfusions* }\end{array}$ & 0 & 1 & 4 & 5 \\
\hline
\end{tabular}

*No other children reported chronic conditions.

Adult cohort

\begin{tabular}{lcccc}
\hline & $\begin{array}{c}\text { Asymptomatic } \\
\mathrm{n}=4\end{array}$ & $\begin{array}{c}\text { Symptomatic } \\
\text { non-hospitalized } \\
\mathrm{n}=8\end{array}$ & $\begin{array}{c}\text { Symptomatic } \\
\text { hospitalized } \\
\mathrm{n}=2\end{array}$ & $\begin{array}{c}\text { Overall } \\
\mathrm{n}=14\end{array}$ \\
\hline Age, median (range) & $69.5(60-79)$ & $65(47-76)$ & $59(54-64)$ & $65(47-79)$ \\
Sex, no. (\%) & $3(75)$ & $4(50)$ & $1(50)$ & $8(57)$ \\
Female & $1(25)$ & $4(50)$ & $1(50)$ & $6(43)$ \\
Male & & &
\end{tabular}




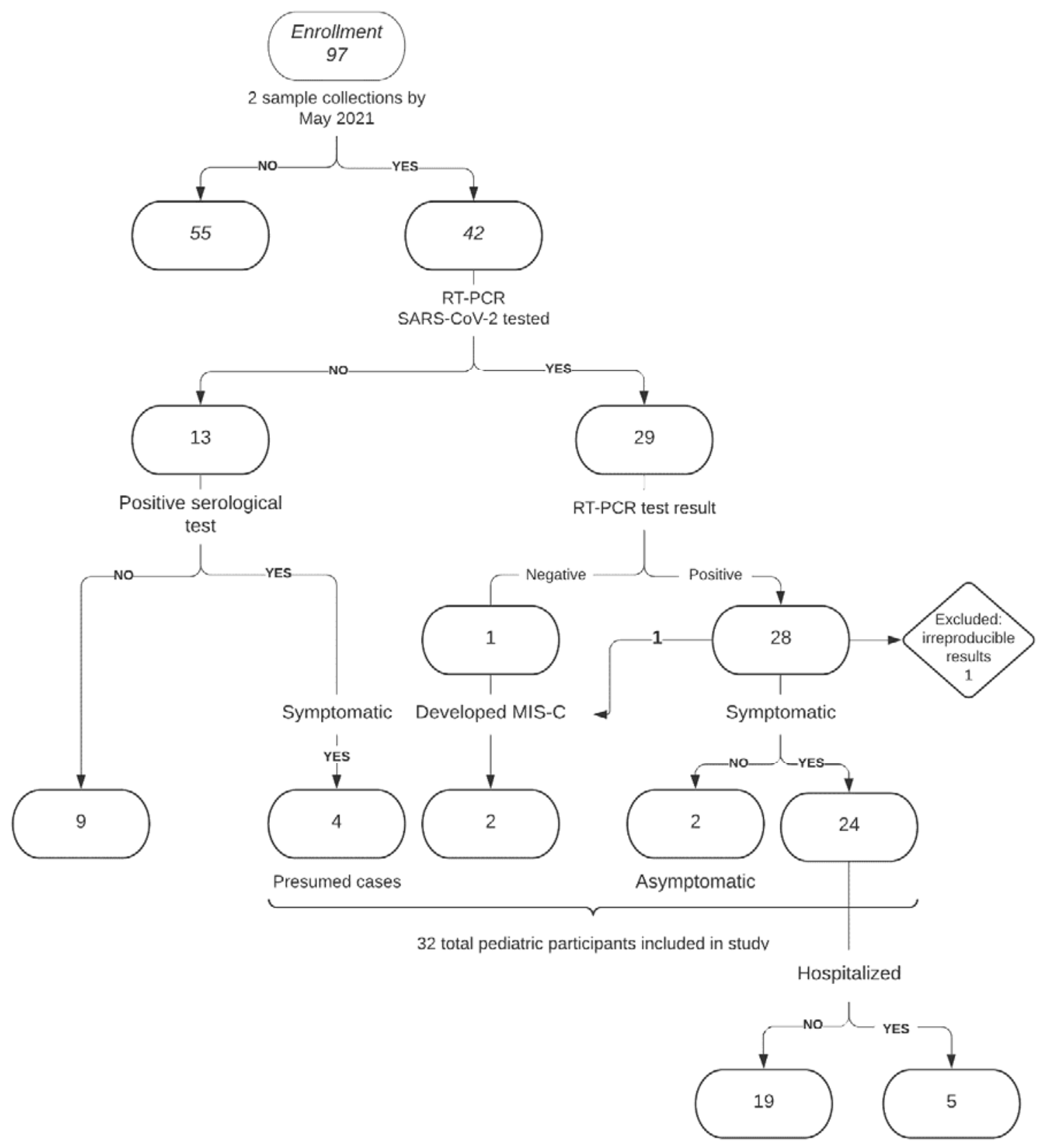

Figure 1. Pediatric study inclusion criteria flowchart. Evidence of infection included a PCR-

701 positive test $(n=28)$ or positive serological test result following a known RT-PCR-positive

702 household exposure $(n=4)$ and/or presentation with MIS-C ( $n=2)$. 
medRxiv preprint doi: https://doi.org/10.1101/2022.01.14.22269235; this version posted January 25, 2022. The copyright holder for this preprint (which was not certified by peer review) is the author/funder, who has granted medRxiv a license to display the preprint in perpetuity.

It is made available under a CC-BY 4.0 International license.

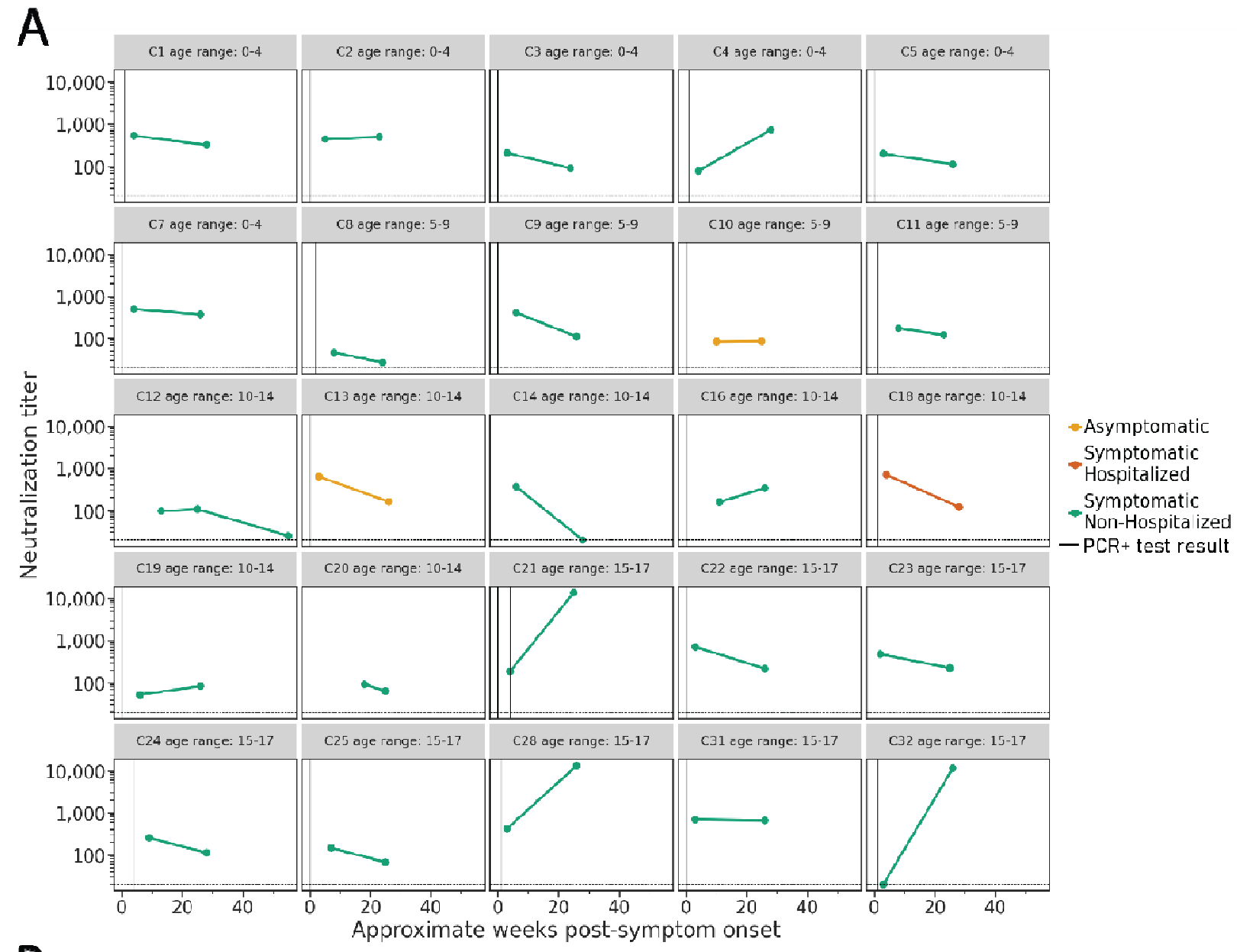

B MIS-C cases

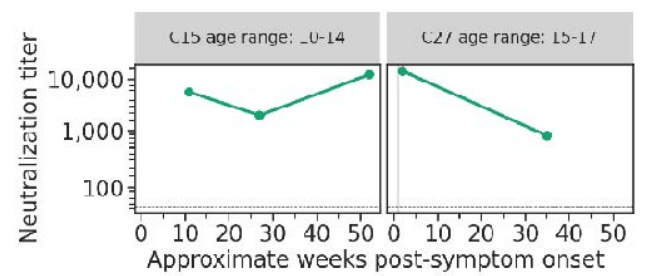

\section{Cases complicated by immunosuppression or multiple transfusions}

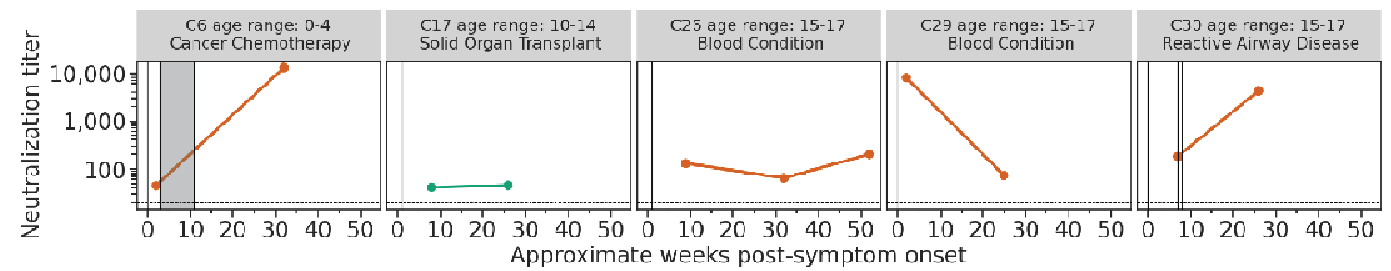

Figure 2: Neutralization titers in children over time. Neutralizing antibody titers $\left(\mathrm{NT}_{50}\right)$ in A) 25 children with confirmed SARS-CoV-2 infection, B) 2 children who developed MIS-C following 
medRxiv preprint doi: https://doi.org/10.1101/2022.01.14.22269235; this version posted January 25, 2022. The copyright holder for this preprint (which was not certified by peer review) is the author/funder, who has granted medRxiv a license to display the preprint in perpetuity.

It is made available under a CC-BY 4.0 International license .

706

707

708

709

710

711

712 acute infection and $\mathbf{C}$ ) cases complicated by immunosuppression $(\mathrm{N}=4)$ or multiple blood transfusions $(\mathrm{N}=1)$ in 5 children with confirmed SARS-CoV-2 infection followed prospectively over time shown as weeks. Vertical lines represent the week of positive RT-PCR test result(s), and shaded areas indicate weeks with consecutive positive RT-PCR test results. Colors show disease severity during acute infection. Dotted horizontal lines indicate the limit of detection (20).

A

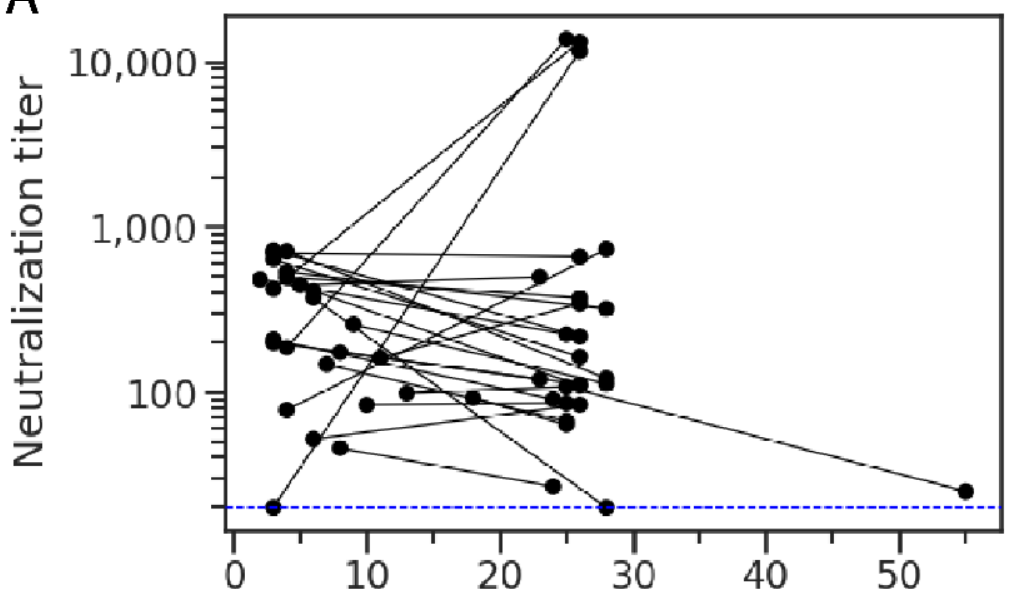

Approximate weeks post-symptom onset

B

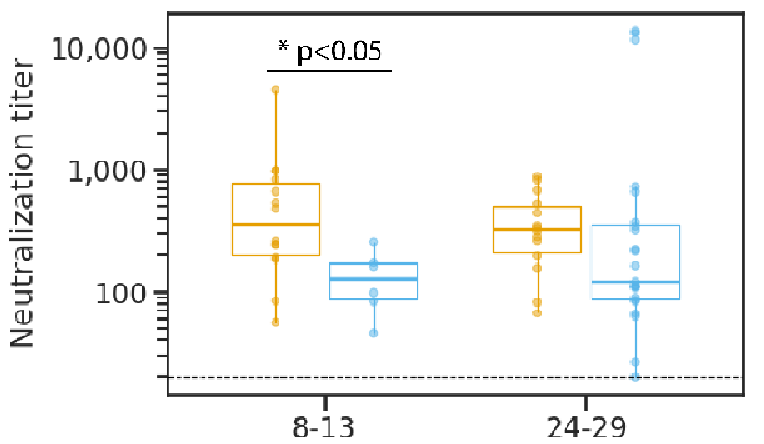

Approximate weeks post-symptom onset

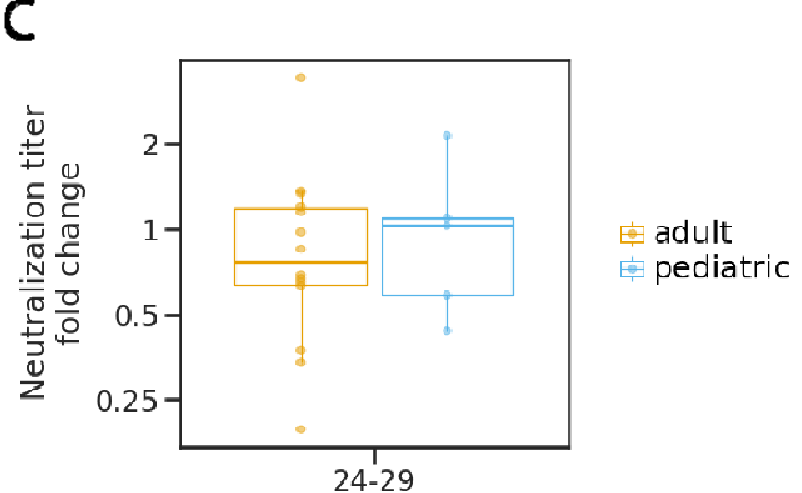

Approximate weeks post-symptom onset

Figure 3. Neutralization potency kinetics in children compared to adults. A) Aggregated

trajectories of pediatric neutralization titers $\left(\mathrm{NT}_{50}\right)$ longitudinally with lines connecting 
medRxiv preprint doi: https://doi.org/10.1101/2022.01.14.22269235; this version posted January 25, 2022. The copyright holder for this preprint (which was not certified by peer review) is the author/funder, who has granted medRxiv a license to display the preprint in perpetuity.

It is made available under a CC-BY 4.0 International license .

716 specimens from the same individual for the 25 pediatric participants without underlying

717 immunosuppression, receipt of multiple blood transfusions, or MIS-C. B) Comparison of adult

718 and pediatric neutralization titers collected within the time periods 8 to 13 weeks (adults $\mathrm{N}=14$;

719 children $\mathrm{N}=7$ ) and 24 to 29 weeks (adults $\mathrm{N}=14$; children $\mathrm{N}=22$ ) for the participants without

720 underlying immunosuppression, receipt of multiple blood transfusions, or MIS-C. C) Analysis of

721 fold change in neutralization titers at 24 to 29 weeks (adults $\mathrm{N}=14$; children $\mathrm{N}=6$ ) relative to

722 titers at 8 to 13 weeks for adults and children without underlying immunosuppression, receipt of

723 multiple blood transfusions, or MIS-C. Significance determined by Mann Whitney test. 
A
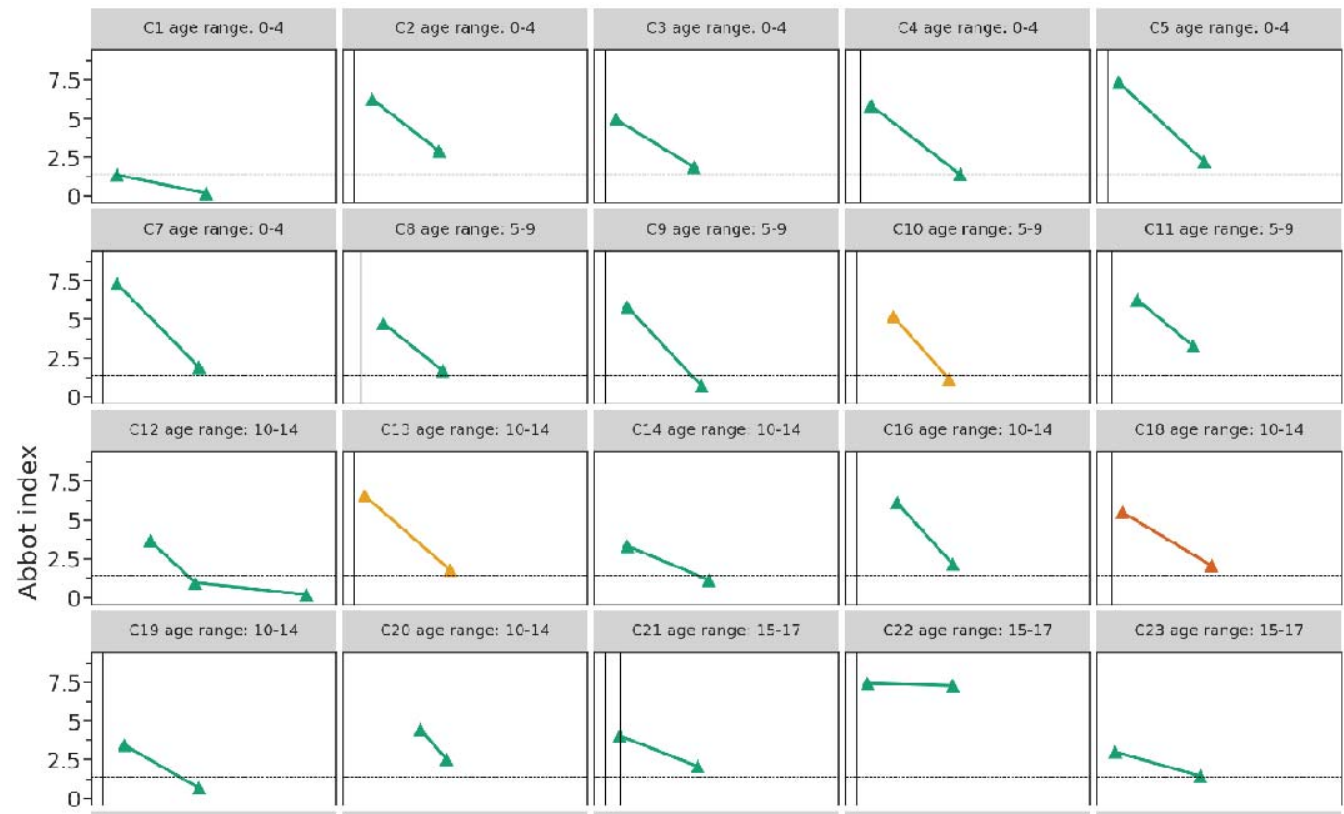

- Asymptomatic Symptomatic Hospitalized

Symptomatic Nor-Hospitalized I PCR+ test result

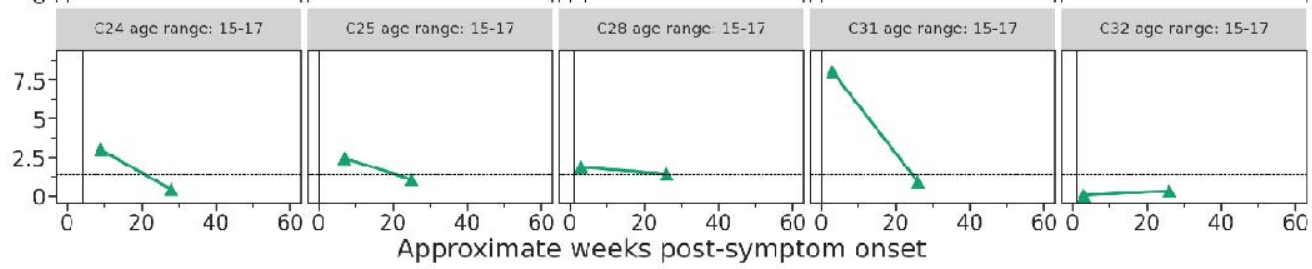

\section{B MIS-C cases}

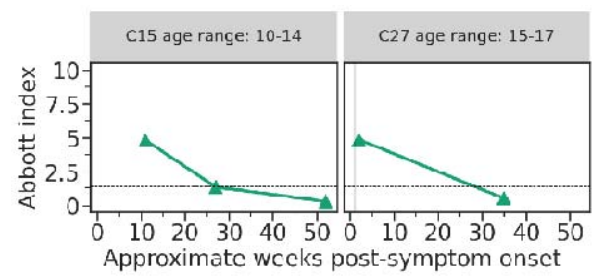

C Cases complicated by immunosuppression or multiple transfusions

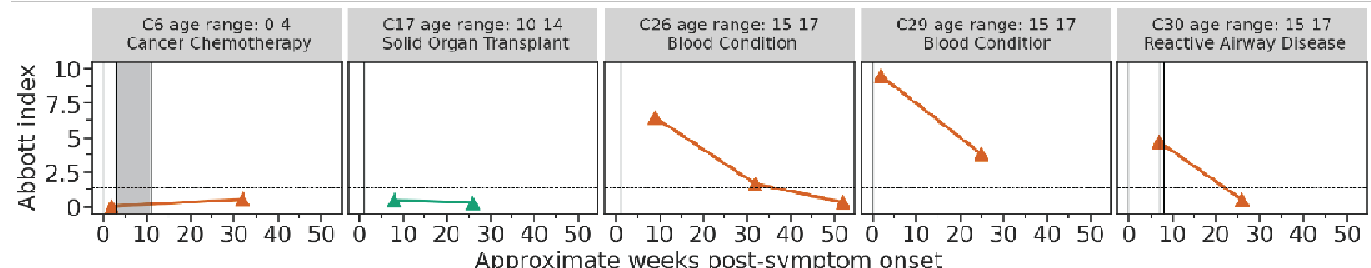

727 following acute infection, and C) cases complicated by immunosuppression or multiple blood 
medRxiv preprint doi: https://doi.org/10.1101/2022.01.14.22269235; this version posted January 25, 2022. The copyright holder for this preprint (which was not certified by peer review) is the author/funder, who has granted medRxiv a license to display the preprint in perpetuity.

It is made available under a CC-BY 4.0 International license .

728

729

730

731

732

733

transfusions in 5 children with confirmed SARS-CoV-2 infection followed prospectively over time shown as weeks. Vertical lines represent the week of positive RT-PCR test result(s), and shaded areas indicate weeks with consecutive positive RT-PCR test results. Colors show disease severity during acute infection. Dotted horizontal lines indicate the limit of detection for the SARS-CoV-2 IgG assay (1.40).

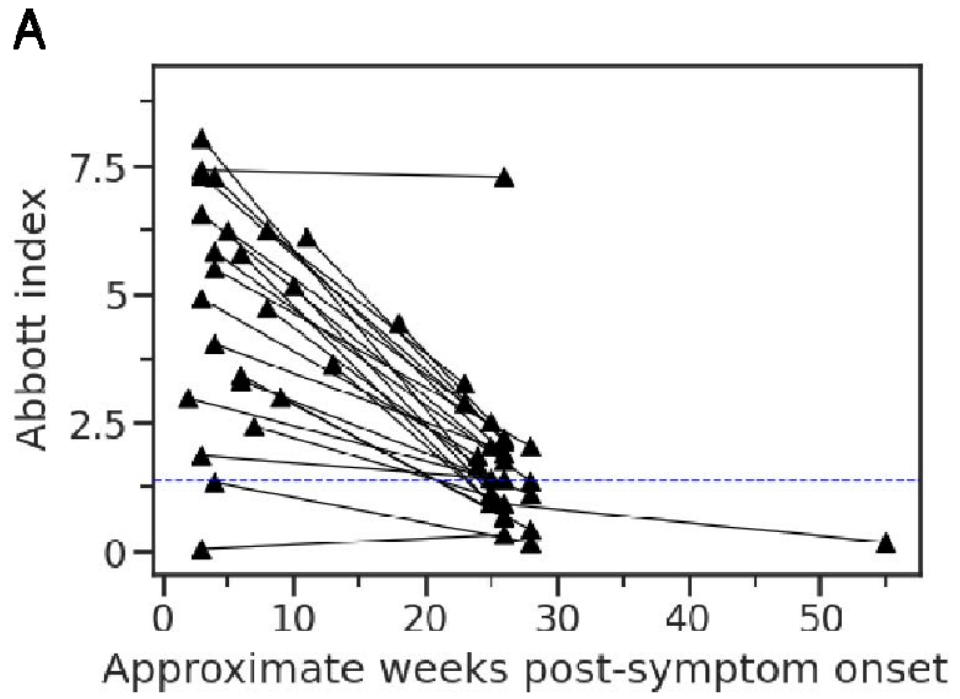

B

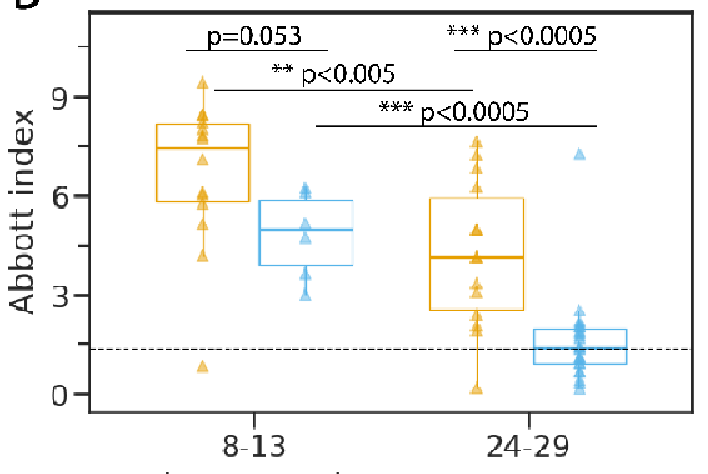

Approximate weeks post-symptom onset

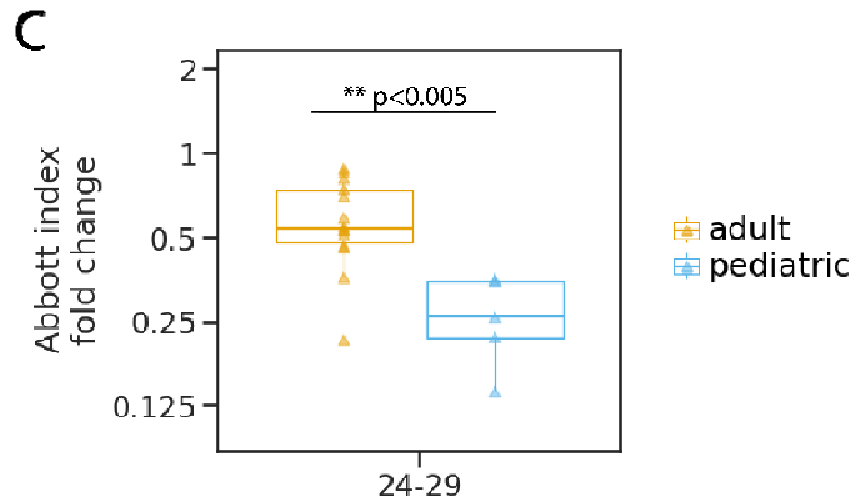

Approximate weeks post-symptom onset
734

735

736

737

Figure 5. Change in nucleocapsid-binding antibody levels longitudinally in children and adults.

A) Aggregated index values for children without immunocompromising conditions over oneyear post-symptom onset with lines connecting specimens from the same individual. B) 
medRxiv preprint doi: https://doi.org/10.1101/2022.01.14.22269235; this version posted January 25, 2022. The copyright holder for this preprint (which was not certified by peer review) is the author/funder, who has granted medRxiv a license to display the preprint in perpetuity.

It is made available under a CC-BY 4.0 International license .

738 Comparison of index values between pediatric and adult cohorts restricted to the same time

739 periods of collection. C) Change in index values at 24 to 29 weeks relative to specimens

740 collected at 8 to 13 weeks for children and adults with specimens collected within both

741 timeframes. Significance determined by Mann Whitney test. Dotted lines indicate the limit of

742 detection for the SARS-CoV-2 IgG assay (1.40).

747 Supplemental Table 1. Evidence of SARS-CoV-2 infection among patients without a confirmed

\begin{tabular}{|c|c|c|c|}
\hline Patient ID & Evidence of SARS-CoV-2 infection & $\begin{array}{c}\text { Epi-week of household } \\
\text { RT-PCR test }\end{array}$ & $\begin{array}{c}\text { Epi-week of participant } \\
\text { symptom onset }\end{array}$ \\
\hline C15 & $\begin{array}{l}\text { Experienced syptomatic infection, developed MIS-C, neutralization } \\
\text { and nucleocapsid antibodies confirmed through serological testing; } \\
\text { this child is listed un the MIS-C subset in inclusion flowchart. }\end{array}$ & not applicable & $\begin{array}{l}2020 \text { week } 11 \text { - acute } \\
2020 \text { week } 18 \text { - MIS-C }\end{array}$ \\
\hline C12 & $\begin{array}{l}\text { Known PCR-positive household infection (family member with long } \\
\text { COVID who was not tested until well after initial household } \\
\text { outbreak), entire family experienced symptoms consistent with } \\
\text { SARS-CoV-2 infection, neutralization and nucleocapsid antibodies } \\
\text { confirmed through serological testing }\end{array}$ & 2020 week 20 & 2020 week 11 \\
\hline $\mathrm{C} 20$ & $\begin{array}{l}\text { Known PCR-positive household infection, experienced symptoms } \\
\text { consistent with SARS-CoV-2 infection, neutralization and } \\
\text { nucleocapsid antibodies confirmed through serological testing }\end{array}$ & unknown & 2020 week 12 \\
\hline $\mathrm{C} 23$ & $\begin{array}{l}\text { Known PCR-positive household infection, experienced symptoms } \\
\text { consistent with SARS-CoV-2 infection, neutralization and } \\
\text { nucleocapsid antibodies confirmed through serological testing }\end{array}$ & $\begin{array}{l}\text { two family members } \\
\text { positive both in } 2020 \\
\text { week } 49\end{array}$ & 2020 week 49 \\
\hline C14 & $\begin{array}{l}\text { Known PCR-positive contacts, experienced symptoms consistent } \\
\text { with SARS-CoV-2 infection, neutralization and nucleocapsid } \\
\text { antibodies confirmed through serological testing }\end{array}$ & 2020 week 48 & 2020 week 48 \\
\hline
\end{tabular}


medRxiv preprint doi: https://doi.org/10.1101/2022.01.14.22269235; this version posted January 25, 2022. The copyright holder for this preprint (which was not certified by peer review) is the author/funder, who has granted medRxiv a license to display the preprint in perpetuity.

It is made available under a CC-BY 4.0 International license.

751

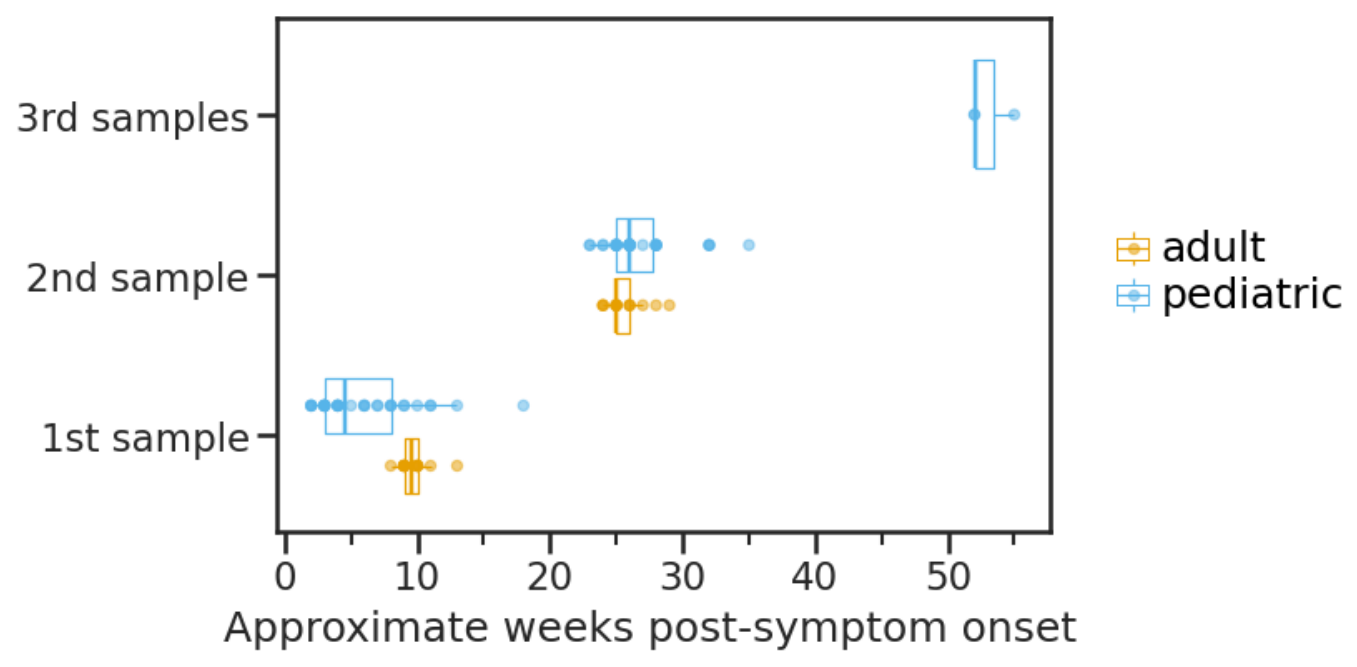

752 Supplemental figure 1. Distribution of specimen collections in children and adults.

753

A

754

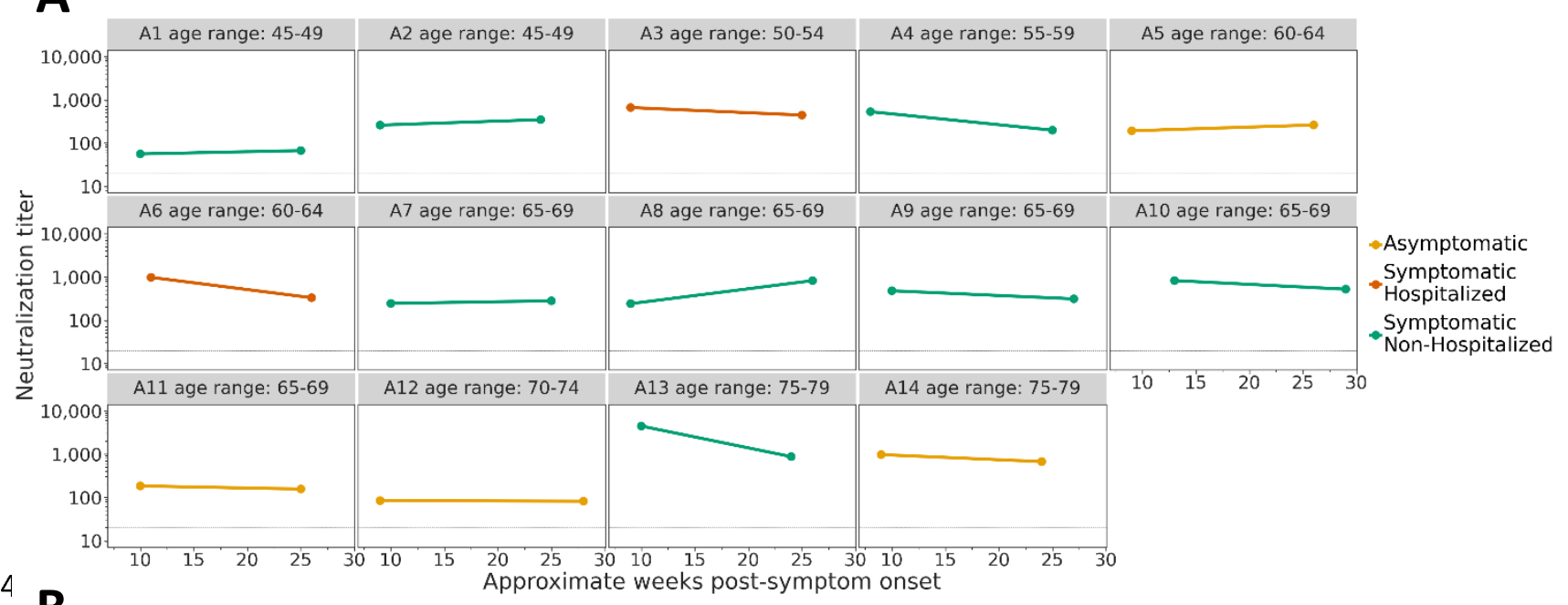


medRxiv preprint doi: https://doi.org/10.1101/2022.01.14.22269235; this version posted January 25, 2022. The copyright holder for this preprint (which was not certified by peer review) is the author/funder, who has granted medRxiv a license to display the preprint in perpetuity.

It is made available under a CC-BY 4.0 International license .

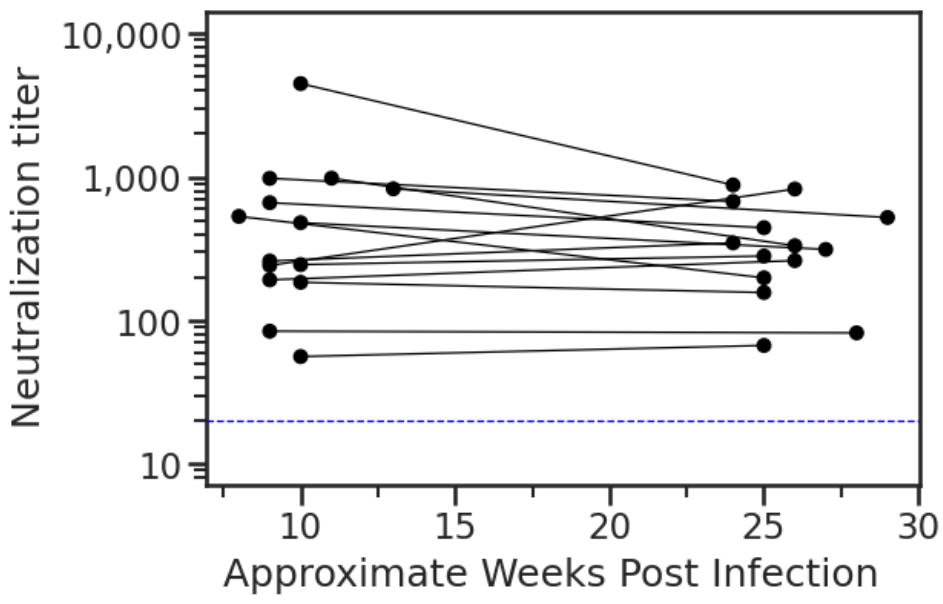

756 Supplemental figure 2. Neutralization titers in adults over time. A) Neutralizing antibody titers

757 in 14 adults with confirmed SARS-CoV-2 infection followed prospectively over time shown as

758 weeks post-symptom onset, $\mathrm{x}$ axis. B) Aggregated neutralization titers for all adults. Dotted

759 horizontal lines indicate the limit of detection (20).

760

761 
medRxiv preprint doi: https://doi.org/10.1101/2022.01.14.22269235; this version posted January 25, 2022. The copyright holder for this preprint (which was not certified by peer review) is the author/funder, who has granted medRxiv a license to display the preprint in perpetuity.

It is made available under a CC-BY 4.0 International license .

A
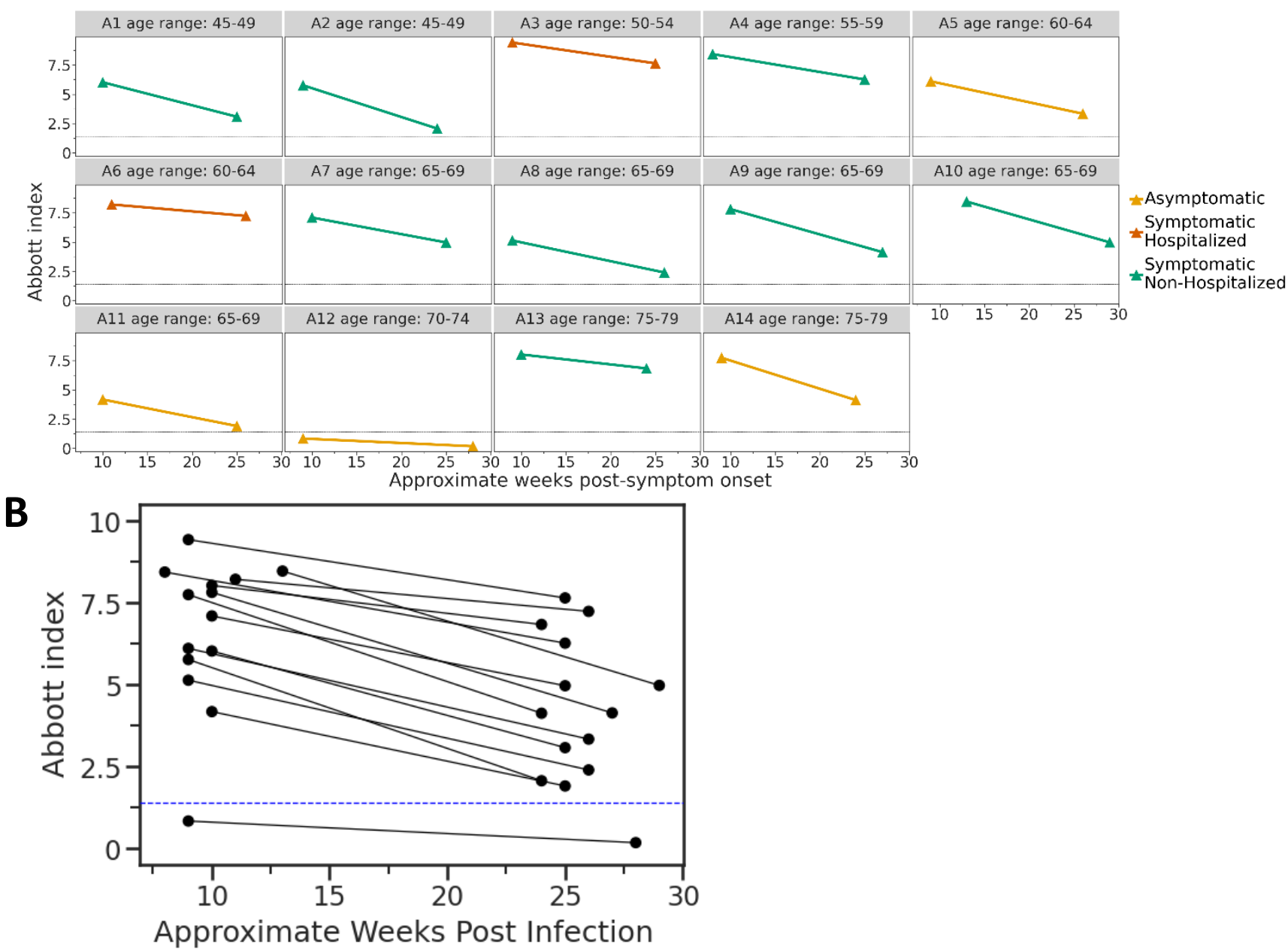

Supplemental figure 3. Nucleocapsid-binding antibody levels in adults over time. A) The

SARS-CoV-2 IgG assay was used to determine SARS-CoV-2 nucleocapsid-binding antibody in

767 Aggregated index values for all adults. Dotted horizontal lines indicate the limit of detection for the SARS-CoV-2 IgG assay (1.40).

Supplemental Table 2. Naming of adults across publications.

Naming in Crawford et al. 2020 (3) Naming in the present study 
medRxiv preprint doi: https://doi.org/10.1101/2022.01.14.22269235; this version posted January 25, 2022. The copyright holder for this preprint (which was not certified by peer review) is the author/funder, who has granted medRxiv a license to display the preprint in perpetuity.

It is made available under a CC-BY 4.0 International license.

772

\begin{tabular}{|l|l|}
\hline PID 13 & A3 \\
\hline PID 3C & A1 \\
\hline PID 4C & A2 \\
\hline PID 6C & A6 \\
\hline PID 7C & A7 \\
\hline PID 11C & A4 \\
\hline PID 12C & A10 \\
\hline PID 22C & A9 \\
\hline PID 23C & A5 \\
\hline PID 24C & A13 \\
\hline PID 113C & \\
\hline
\end{tabular}

